\title{
Working
}

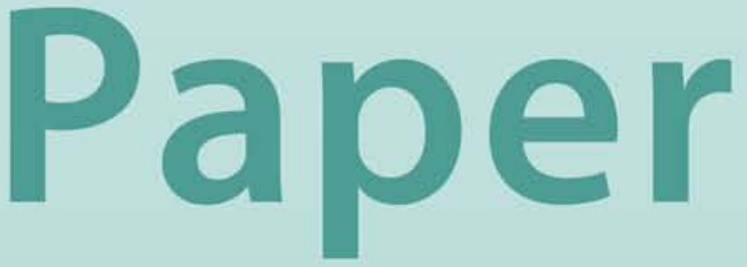




\section{Do Financial Sector Reforms Lead to Financial Development? Evidence from a New Dataset} Thierry Tressel and Enrica Detragiache 


\section{IMF Working Paper}

Research Department and IMF Institute

\section{Do Financial Sector Reforms Lead to Financial Development? Evidence from a New Dataset}

\section{Prepared by Thierry Tressel and Enrica Detragiache ${ }^{1}$}

Authorized for distribution by Enrica Detragiache

December 2008

\begin{tabular}{|l|} 
Abstract \\
\begin{tabular}{|l|}
\hline This Working Paper should not be reported as representing the views of the IMF. \\
The views expressed in this Working Paper are those of the author(s) and do not necessarily represent \\
those of the IMF or IMF policy. Working Papers describe research in progress by the author(s) and are \\
published to elicit comments and to further debate.
\end{tabular} \\
\hline
\end{tabular}

This paper studies whether the policies that, over the past decades, liberalized banking systems around the world have resulted in deeper credit markets. To measure banking sector reforms we use a new index that tracks policy changes in five separate areas for 91 countries over 1973-2005. We find that reforms have led to financial deepening, but only in countries with institutions that place checks and balances on political power. We interpret this as evidence of a complementarity between financial sector reforms and political institutions that protect property rights. Other country characteristics do not seem to significantly influence the effect of banking reforms on financial development.

JEL Classification Numbers: O16, G28, G18

Keywords: Financial development, financial liberalization, property rights

Authors’ E-Mail Address:TTressel@imf.org ; EDetragiache@imf.org

\footnotetext{
${ }^{1}$ We wish to thank Olivier Jeanne, Raju Singh, Antonio Spilimbergo and seminar participants at the Research Department and at the Institute of the IMF for very useful comments. Ermal Hitaj provided excellent research assistance.
} 


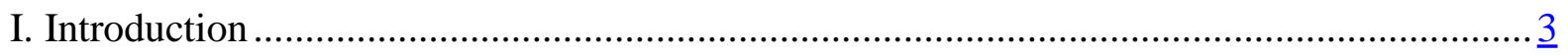

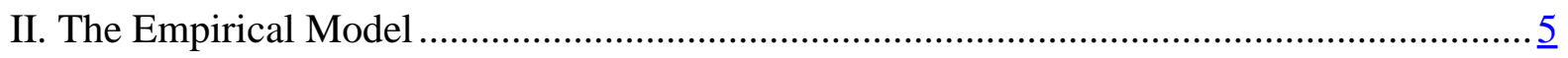

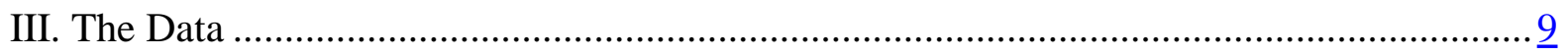

IV. Estimation Results.................................................................................... 13

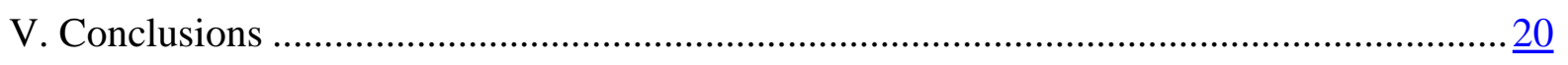

Tables

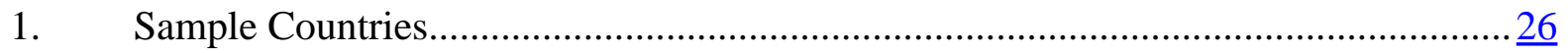

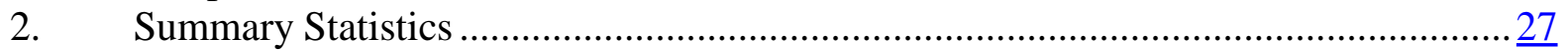

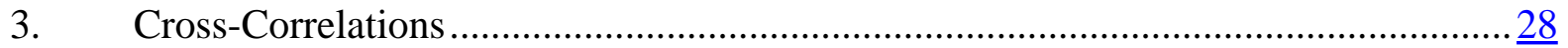

4. Baseline Regression: Two Alternative Maximum Lags...........................................29

5A. What Explains the Lack of Sustained Effect of Reforms on Financial Depth in Developing Countries? Shocks, Policies, Non-Linearities .................................... 31

5B. What Explains the Lack of Sustained Effect of Reforms on Financial Depth in Developing Countries? Institutions .................................................................... 32

6. Regressions Countries with Good Property Rights ............................................. $\frac{33}{34}$

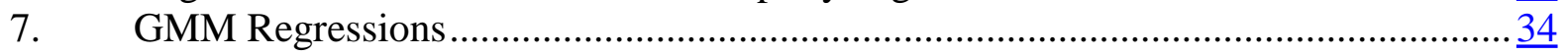

8. Regressions with 5 Year Periods Panels .......................................................... $\frac{35}{36}$

9. Impact of Specific Banking Sector Reforms on Financial Depth ............................. 36

\section{Figures}

1. Financial Reforms by Regions .................................................................... 37

2. $\quad$ Private Credit to GDP Around Episodes of Banking Reform ................................. $\underline{38}$

3. Financial Depth and Banking Reform Index-evolution of cross-sectional dispersion $\underline{38}$

4. Financial Depth and Banking Reform Index-correlation over time.......................... $\underline{39}$

5. Estimated Effect of Banking Reforms on the Private Credit to GDP Ratio................ $\underline{40}$

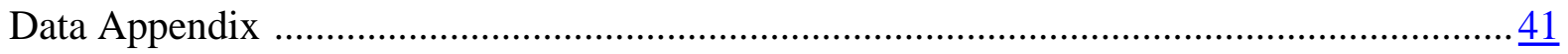

Appendix

Empirical Specification …................................................................................. 42

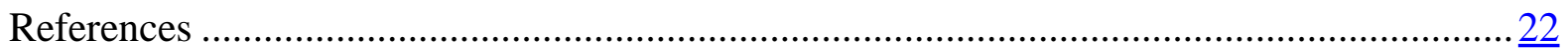




\section{INTRODUCTION}

The role of finance in economic development and its importance for economic growth have long been studied and debated (Levine, 1997, 2005). A central question in this literature is why financial markets are deeper in some countries than in others, and which specific policies might accelerate financial development where it lags behind. In this paper, we study the effects on financial development of the financial liberalization policies that most countries around the world implemented during the last 30 years. Have these policies delivered deeper financial markets as they intended?

The impetus to reduce the role of the state in financial markets is often attributed to the influential work of McKinnon (1973) and Shaw (1973). These authors argued that widespread interference by the state in financial markets, through government ownership of banks, interest rate regulation, high bank reserve requirements, stringent entry restrictions, mandatory credit allocation to preferential sectors, etc., was responsible for low deposit interest rates resulting in low financial savings, high lending interest rates, monopoly power by banks, low financial intermediation, and concentration of credit in favored sectors and firms, especially in developing countries.

Heeding the advice of McKinnon and Shaw, many countries undertook to dismantle "financial repression” policies during the last 30 years, although to a different extent and at a different pace in the various regions of the world. A new IMF database tracks progress in numerous dimensions of financial sector reforms, providing the most comprehensive yardstick to date to measure financial liberalization (Abiad, Detragiache, and Tressel, 2008). ${ }^{2}$

In this paper, we explore whether financial reforms have led to deeper financial markets, as predicted by McKinnon and Shaw. We also explore how institutions have shaped the response of the financial sector to reform policies. A large body of research has indeed shown that the cross-section of financial sector development is explained by a variety of institutional country characteristics, such as legal origin (La Porta and others, 1998), contracting right institutions (Djankov, MacLiesh, and Shleifer, 2007), property right institutions (Acemoglu and Johnson, 2005), and political stability (Roe and Siegel, 2008). This research suggests that the institutional environment has an important impact on the functioning of the financial sector.

In contrast with most of the literature on the determinants of financial development, our objective is to mainly explain the time variation of financial development within countries, not its cross-sectional variation. ${ }^{3}$ This reflects our interest in identifying the effects of policy changes within each country, instead of the effect of slow-moving factors. For this purpose, we estimate a dynamic autoregressive distributed lag model linking financial development to the

\footnotetext{
${ }^{2}$ This database extends an earlier database used by Abiad and Mody (2005) to study the determinants of financial sector reform.

${ }^{3}$ As noted by Braun and Raddatz (2008), this time series variation is substantial and well-worth investigating.
} 
new financial reform index for a panel of 85 countries over 1978-2005. This empirical framework also allows us to distinguish between short-run and long-run effects of policy changes. This is important, because, in principle, the effects of reforms may work at different lags, and short-term effects may differ from long-run effects. ${ }^{4}$ In addition, to explore the complementary role of institutions, the baseline model is estimated for various subsamples, selected on various institutional characteristics.

We find that financial liberalization policies do increase financial development in the long run, but only in countries with well-developed political institutions to limit the power of the executive. We do not find any sustained effects of banking reforms in other countries. This evidence suggests that ensuring adequate checks and balances on political power-as a necessary step to improve the protection of property rights - may be a necessary condition for the banking system's functioning to improve after liberalization. This is consistent with Acemoglu and Johnson (2005), who find that more stringent constraints on the executive has a significant positive effect on growth, investment, and financial development. The interpretation is that political checks and balances protect citizens from expropriation from politically powerful elites, thereby safeguarding property rights. ${ }^{5}$ A good protection of property rights, in turn, ensures that potentially all agents in the economy can access financial sector loans when they qualify. We also find that other institutions or policies - most notably the quality of financial sector supervision and regulation — do not seem to matter in shaping the response of financial sector development to banking reforms. ${ }^{6}$ Our results are robust to omitted variable and reverse causality bias.

The paper is related to various strands of the literature. As mentioned, a large literature studies the determinants of financial development, often focusing on the cross-sectional variation. Some studies have looked at the role of macroeconomic factors (Boyd, Levine, and Smith, 2001); the ownership of banks (La Porta and others, 2002; Detragiache, Tressel, and Gupta, 2008); and the role of institutions, as already discussed. Moreover, Braun and Raddatz (2007) and Baltagi, Demetriades, and Law (2007) explore political economy theories of financial development by testing the hypothesis of Rajan and Zingales (2003), that financial development tends to occur when economies are opened up to foreign competition, so that the rents of incumbents are eroded. Chinn and Ito (2006) focus on the effect of removing restrictions on international financial transactions (capital account liberalization) on various indicators of financial development. They find that capital account liberalization leads to stock market development

\footnotetext{
${ }^{4}$ An example is when financial liberalization triggers a credit boom that ends in a crash. The short-run effect of the policy measure on credit could be positive and large, but the long-run effect will be negligible or even negative. For a detailed analysis of credit booms, see for instance Mendoza and Terrones (2008).

${ }^{5}$ Acemoglu and Johnson's results hold measuring property rights using an index of protection from expropriation instead of the index of constraints on the executive. We find the same result. See also Acemoglu, Johnson and Querubin (2008) on the effectiveness of central bank independence in taming inflation in countries with intermediate property right protection.

${ }^{6}$ However, we do find that macroeconomic policies, in themselves, directly affect financial development.
} 
only in countries with sufficiently developed legal systems, while the effect is negative in other countries.

Several papers study the effects of specific financial sector reform episodes. For instance, Rajan and Zingales (1998) show that, across countries, financial development benefits industries dependent on external finance relatively more than other industries. The relaxation of interstate banking and branching restrictions in the U.S. in the 1980s is found to have caused faster economic growth (Jayaratne and Strahan, 1996), to have made bank lending decisions more sensitive to firm performance (Stiroh and Strahan, 2003), and to have reduced entry barriers and improved access to finance for small-sized firms (Cetorelli and Strahan, 2006). In France, Bertrand, Schoar, and Thesmar (2004) find that after bank deregulation poorly performing firms were no longer bailed out by banks, resulting in more rapid industrial restructuring. In Italy, bank deregulation has led to improved access to credit and lower interest rate spreads, but also more nonperforming loans (Guiso, Sapienza, and Zingales, 2006). In a large sample of countries, Tressel (2008) finds that financial reforms disproportionately benefit industries that are more dependent on external finance, but that the differential positive effect weakens in countries with a poor protection of property rights.

Financial liberalization has been associated with a higher incidence of banking crises (Demirgüç-Kunt and Detragiache, 1999), more output volatility (Kaminsky and Schmukler, 2003), but a more efficient allocation of investment (Galindo, Schiantarelli, and Weiss, 2007, Chari and Henry, 2008, and Abiad, Oomes, Ueda, 2008). Finally, Agca, De Nicolo', and Detragiache (2008) examine how financial reforms and globalization change corporate leverage. They find that domestic liberalization results in higher leverage in advanced country corporations but lower leverage in emerging market corporations. They interpret this finding as evidence domestic liberalization has not succeeded in lowering the cost and improving access to credit in emerging markets.

The paper is organized as follows: we present the empirical model in the next section. Section III describes the data. Section IV contains the main results, and Section V concludes.

\section{THE EMPIRICAL MODEL}

To assess the dynamic effects of banking sector liberalization on the process of financial development, we consider a general dynamic auto-regressive distributed lag model linking financial development $y_{i t}$ in country $i$ at date $t$, to an index of banking sector liberalization $I_{i t}$, and a vector of macroeconomic control variables $X_{i t}$. Specifically, we assume the following generalized dynamic panel relationship between banking sector depth and the level of the liberalization index:

$$
y_{i, t}=\alpha_{0}+\sum_{j=1}^{N} \beta_{j} \cdot y_{i, t-j}+\sum_{j=0}^{N} \gamma_{j} \cdot I_{i, t-i}+\sum_{j=0}^{N} \varphi_{j} \cdot X_{i, t-i}+\varepsilon_{i t}
$$


where $\alpha_{0}, \beta_{j}, \gamma_{i}$ and $\varphi_{i}$ are parameters to be estimated, $N$ is the maximum number of lags, and $\varepsilon_{i t}$ is an error term. We assume that $\varepsilon_{i t}=f_{i}+d_{t}+v_{i t}$ where $f_{i}, d_{t}$ are a set of country fixed effects and year fixed effects, and $v_{i t}$ is a standard error term. Countries fixed effects control for time-invariant, unobserved country factors that could affect the levels of financial depth and liberalization and also control for possible systematic differences across countries in the measurement of variables of interest. ${ }^{7}$ Year fixed effects control for global comovements in the levels of the variables of interest. For example, they control for the fact that the levels of financial liberalization could follow the same trend in all countries, reflecting for instance technological progress in banking.

With this specification, identifying empirically the time it takes for banking sector reforms to affect credit to the private sector is likely to be difficult because the banking sector liberalization index is highly persistent within countries. Indeed, when we run a simple OLS regression with country and year fixed effects, the coefficient on the first lag of the index is 0.86 . This high persistence may, in practice, introduce multicollinearity problems.

For this reason, we rearrange the equation to estimate a relationship between the (log) change in financial development and changes in the banking sector liberalization index $\Delta I_{t-k}$ (the formal derivation is in the appendix). In this error-correction specification, the level of the index appears only once, with $\mathrm{N}$ lags, and the change in the index $\Delta I_{t-k}$ measures a banking sector reform occurring at date $t-k$ :

$$
\begin{aligned}
& \Delta y_{i t}=\alpha_{0}+\sum_{j=1}^{N-1}\left(\sum_{u=1}^{j} \beta_{u}-1\right) \cdot \Delta y_{i, t-j}+\left(\sum_{u=1}^{N} \beta_{u}-1\right) \cdot y_{i, t-N}+\sum_{j=0}^{N-1}\left(\sum_{u=0}^{j} \gamma_{u}\right) \cdot \Delta I_{i, t-j}+\sum_{j=0}^{N-1}\left(\sum_{u=0}^{j} \varphi_{u}\right) \cdot \Delta X_{i, t-j} \\
& +\left(\sum_{u=0}^{N} \gamma_{u}\right) \cdot I_{i, t-N}+\left(\sum_{u=0}^{N} \varphi_{u}\right) \cdot X_{i, t-N}+\varepsilon_{i t}
\end{aligned}
$$

Define the parameters (where $\lambda_{j}$ and $\mu_{j}$ are scalars and $\theta_{j}$ is a vector):

$$
\left\{\begin{array}{l}
\lambda_{j}=\sum_{u=1}^{j} \beta_{u}-1 \\
\mu_{j}=\sum_{u=0}^{i} \gamma_{u} \\
\theta_{j}=\sum_{u=0}^{i} \varphi_{u}
\end{array}\right.
$$

Thus, we estimate equation (2) as follows, with data on an annual frequency:

\footnotetext{
${ }^{7}$ For example, slow-moving broad institutional characteristics are captured by the country fixed effect. The country fixed effect also captures any systematic biases in measuring levels of liberalization across countries.
} 


$$
\begin{aligned}
& \Delta y_{i t}=\alpha_{0}+\sum_{j=1}^{N-1} \lambda_{j} \cdot \Delta y_{i, t-j}+\lambda_{N} \cdot y_{i, t-N}+\sum_{j=0}^{N-1} \mu_{j} \cdot \Delta I_{i, t-j}+\sum_{j=0}^{N-1} \theta_{j} \cdot \Delta X_{i, t-j} \\
& +\mu_{N} \cdot I_{i, t-N}+\theta_{N} \cdot X_{i, t-N}+\varepsilon_{i t}
\end{aligned}
$$

In this model, the cumulative direct effect of a reform episode occurring at date $t-i$ on financial deepening of date $t$ of date is given by $\mu_{i}$. As a result of persistence in the levels of financial development, there are also indirect effects of past reforms on the current financial deepening through their effects on lagged values of the dependent variable. The long-run direct and indirect effects of financial reforms and the other control variables on financial development can be easily obtained from the coefficients of equation (3). Specifically, the longrun effect of financial reforms is equal to:

$$
-\frac{\mu_{N}}{\lambda_{N}}=-\frac{\sum_{u=0}^{N} \gamma_{u}}{\sum_{u=1}^{N} \beta_{u}-1} .
$$

The long-run effect of the control variables on financial development is:

$$
-\frac{\theta_{N}}{\lambda_{N}}=-\frac{\sum_{u=0}^{N} \varphi_{u}}{\sum_{u=1}^{N} \beta_{u}-1} .
$$

Finally, the error term $v_{i t}$ is assumed to be independently distributed. At a minimum of robustness, standard errors are clustered by country to allow for heteroskedasticity and possible serial correlation in the error term.

An alternative approach to our empirical strategy of relying on a dynamic, autoregressive, distributed lag model estimated at an annual frequency is to test for a long-run relationship using panel data averaged over a longer period. The reasons for preferring our approach are the following. ${ }^{8}$ First, some information on reforms may be lost when averaging. This is particularly problematic for the financial reform indices, which vary significantly over time within countries (see Figure 1). By averaging, we may not be able to econometrically identify the effect of a particular reform on financial deepening. Indeed, reforms may follow a smooth, gradual process, rather than being one-off, "big bang” events. Thus, comparing average levels of financial development over arbitrarily defined periods may hide the effects of gradual reforms. Second, when averaging, the length and start date of the period are arbitrary and are constrained to be the same for all countries, yet the duration of the business cycle or of convergence to the steady-state may vary over time and across countries. As a result, time-averaging may not remove (just) business cycle fluctuations. Third, by time-averaging it is not possible to study the potential dynamic effects of reforms. For example, a reform may have a temporary effect that

\footnotetext{
${ }^{8}$ See Attanasio, Picci and Scorcu (2000) for a discussion on the use of annual data in panel regressions.
} 
may be economically relevant and important to identify, even though the medium-term or longrun effect may be small. Alternatively, the effects of reforms may materialize only after several years. For these reasons, while we also report regressions with time-averaged data as a robustness test, most of analysis will be conducted using annual data.

In the robustness tests with time-averaged data, we use a panel of non-overlapping five-year periods between 1980 and 2005. With the data organized in this fashion the error-correction model to be estimated becomes: ${ }^{9}$

$$
\Delta y_{i, t, t-5}=y_{i t}-y_{i t-5}=\lambda \cdot y_{i, t-5}+\mu \cdot \Delta I_{i, t, t-5}+\theta \cdot \Delta X_{i, t, t-5}+\varphi \cdot I_{i, t-5}+\phi \cdot X_{i, t-5}+\omega_{i t}
$$

where $\omega_{i t}=f_{i}+d_{t}+\tau_{i t}$, with $f_{i}, d_{t}$ are a set of country fixed effects and year fixed effects, and $\tau_{i t}$ is an error term.

The baseline model is estimated separately for subsamples of observations grouped on the basis of various institutional variables. For instance, we will run separate regression for countries with French legal origin and Anglo-Saxon legal origin. If the coefficient of the effect of reforms on financial development and reforms differs in the two subsamples, we will interpret it as evidence that institutions help shaping how the financial system responds to reforms. ${ }^{10}$

\section{Estimation technique}

We estimate the baseline empirical model with OLS controlling for country and year fixed effects. With lagged dependent variables, OLS coefficients are biased, but the size of the bias declines as the time dimension grows (Nickell, 1981). ${ }^{11}$ We therefore test the robustness of the results using the system GMM estimator of Arellano and Bover (1995) and Blundell and Bond (1998), as GMM coefficient estimates are unbiased in the presence of lagged endogenous variables even when $\mathrm{T}$ is small. We also conduct additional tests using the difference GMM estimator developed by Arellano and Bond (1991). ${ }^{12}$

In the GMM empirical model, we adopt the rather conservative assumption that all reform episodes $\Delta I_{t}$ to $\Delta I_{t-4}$ are potentially endogenous. Our identification assumption is that lags of

\footnotetext{
${ }^{9}$ We do not consider lags longer than five years to minimize the loss of information, since identification is based on the within dimension of the sample.

${ }^{10}$ An alternative approach to splitting the sample would be to introduce interaction terms between the reform index and institutional proxies. However, this would be unwieldy given the large number of lags.

${ }^{11}$ The size of the bias is of the order of $1 / T$, which, in our case with an average of 24 years of observations, introduces a bias of about 0.04 .

12 The difference GMM estimator is biased and has been shown to perform poorly when the dependent variable is persistent, because lagged levels of the dependent variables are poor instruments for the variables in differences (Blundell, Bond and Windmeijer, 2000). For this reason, we mainly report estimations using the system GMM.
} 
five years or longer of the right hand side variables Zs are valid instruments for the lags of the dependent variable and those of the banking reform index. Given that reform episodes up to four lags will be instrumented, this implies that up to nine lags of the right hand side variables are considered as instruments. Formally, the exclusion restrictions of the system GMM are:

$$
\left\{\begin{array}{l}
E\left(\Delta Z_{i t-k}, \varepsilon_{i t}\right)=0 \\
E\left(Z_{i t-k}, \Delta \varepsilon_{i t}\right)=0
\end{array} \quad \text { with: } \quad 5 \leq k \leq 9\right.
$$

GMM estimation should also correct for possible biases coming from correlation of the explanatory variable with the error term, as would be the case in the presence of omitted variables or reverse causality. In the case at hand, the potential endogeneity of the banking reform process is a concern. Indeed, a reform episode may be triggered by an unobserved factor that also results in an expansion of bank credit to the private sector. For example, good news about future growth prospects may simultaneously increase the likelihood of a reform and cause an expansion of credit to the private sector. Alternatively, reform episodes may be more likely to take place when credit is expanding.

To further ascertain that endogeneity of financial reforms is not biasing our results we perform the following additional tests, discussed in more detailed in Section IV. First, we perform falsification tests: if the result was driven by an intensification of reforms during good times, a positive and significant correlation between reforms in other areas and financial development should also be observed. We will check that this is not the case. Second, we develop an instrumental variable strategy to correct potential endogeneity bias.

\section{THE DATA}

\section{The dependent variable and the control variables}

The dependent variable is the ratio of bank credit to the private sector to GDP, which measures the degree of bank intermediation toward the private sector. This is one of the most widely used measures of financial development, as it is available for many countries and time periods. ${ }^{13}$ Replicating our regressions using the ratio of bank deposits to GDP yields only minor differences. Our main explanatory variable is an index of domestic banking reforms from Abiad, Detragiache and Tressel (2008). This index measures banking reforms for a set of 91 countries over 1973-2005 in five areas (credit controls and reserves requirement, interest rate controls, entry barriers, state-ownership and banking supervision). These authors also construct an index of policies to stimulate the development of bond and stock markets, and index of capital account liberalization.

We focus mainly on bank lending rather than broader financial sector development because indexes measuring the development of securities markets that date back to the late 1970s are not available for a large cross-section of countries. In addition, the reform index of Abiad,

${ }^{13}$ Data sources are in Table A.1. 
Detragiache and Tressel (2008) is mainly focused on policy changes affecting the banking sector, and policy reforms impacting securities markets may be less precisely measured. While this is a limitation of our study, it is a relatively minor one, since the banking system remains at the core of the financial sector in most countries in the world.

Besides including country and time fixed effects to control for time-invariant country characteristics and global trends respectively, we also control for the overall level of development of the country through GDP per capita. A second control variable is inflation, which studies find to significantly reduce financial depth (Boyd, Levine, and Smith, 2001). We introduce a number of additional control variables (and their lags) in robustness checks: the fiscal balance as a share of GDP, as large fiscal deficits may lead to macroeconomic instability and may crowd-out private investment, thus hampering financial development; ${ }^{14}$ reforms aimed at developing securities markets and liberalizing international capital flows, using indexes from Abiad, Detragiache, and Tressel (2008); and the average tariff level, measuring the restrictiveness of the international trade regime, from IMF (2008).

Institutions and macroeconomic performance have been found to play a major role in shaping the development of financial systems around the world, therefore it is interesting to explore whether the response of financial deepening to reform depends on the institutional environment. As discussed above, we do so by reestimating the baseline model for subsamples grouped according to specific macroeconomic and institutional characteristics.

Concerning macroeconomic performance, we test whether the response of financial development to reform differs if we exclude from the sample observations corresponding (in turn) to banking crisis, to periods of high inflation, and to periods of large fiscal deficits.

Several broad institutional characteristics impacting financial development have been emphasized in the recent literature.

La Porta and others (1998) finds that countries with English legal origin have deeper financial markets while the French legal tradition seems to hinder financial development. The result is attributed to the higher legal formalism and more costly contract enforcement associated with French legal origin. We will test whether legal origin affects the response of the banking sector to financial liberalization.

Next, we also test whether the response to financial reforms is affected by political institutions. Acemoglu and Johnson (2005) shows that institutions that constrain expropriation by the elite or the state have a positive first order effect on financial development, while contracting right institutions - defined as institutions supporting private contracts—seem only to affect the form of financial intermediation. We conjecture that political institutions that protect from expropriation are necessary for liberalized financial sectors to work properly for two reasons. First, with a high risk for expropriation by the state, economically viable projects may not generate profits appropriated by banks through loan repayments. Thus, even if banks are

\footnotetext{
${ }^{14}$ See for example Hauner (2008).
} 
efficient and liquid, there may not be profitable projects to finance from the viewpoint of banks. Second, in countries with few curbs on the power of the executive banks themselves may be threatened by expropriation or political interference in their lending decision, even though the financial system has moved away from financial repression. As a result, banks may lend only to the government of powerful groups.

Following Acemoglu and Johnson (2005), we will use the de jure Polity IV index of constraints on the executive as our main measure of political checks and balances. ${ }^{15} \mathrm{We}$ also consider alternative proxies, namely the Heritage Foundation property right index, and the index of protection against expropriation of Political Risk Services (first used by Knack and Kiefer, 1995). The first index is available from 1996 onwards, while the second covers the period 1982-97.

We also explore whether the response to reforms is affected by the quality of contracting institutions. Djankov, Mc Liesh and Shleifer (2007) develops an index of the degree to which creditor rights are protected in bankruptcy covering 129 countries between 1980 and 2005. This study finds that the protection of creditor rights through the legal system and information sharing arrangements affect the development of banking systems.

Finally, as an extreme form of weak property and contracting rights, periods of political instability may also hinder the development of financial systems (Roe and Siegel, 2008). We will use indices of internal and external conflicts from the ICRG available from 1984 onwards as measures of political instability.

As shown in the literature, property right institutions and creditor right institutions are quite stable over time. Therefore, their direct effect on financial development is absorbed by the country fixed effects, while the direct effect of pure financial reforms is identified within countries. However, the effect of pure financial reforms may depend on the overall property right and contracting right environment, as we shall see in our analysis.

\section{The financial reform data}

To measure domestic financial reforms, we use an index derived from the database of Abiad, Detragiache and Tressel (2008), which covers 91 countries from 1973 to 2005. The index is the normalized sum of five subindexes that track the presence of restrictions in the following areas: the Credit controls and reserve requirements subindex codes the tightness of mandatory bank reserve requirements, the existence of compulsory credit allocation requirements, the presence and extent of subsidized credit schemes, and the existence of quantitative restrictions on bank credit growth. The Interest rate controls subindex reflects the extent to which deposit and lending rates are market determined rather than subject to administrative ceilings. The Entry barriers subindex tracks restrictions on entry into the banking sector, including restrictions on foreign bank entry, as well as restrictions on branching and scope of bank activities. The Bank privatization subindex codes the extent to which bank assets are controlled by private owners

\footnotetext{
${ }^{15}$ The Polity IV database can be found at: http://www.systemicpeace.org/polity/polity4.htm.
} 
rather than the government. Finally, the Bank supervision subindex varies according to whether Basel capital regulation and a number of characteristics of the bank supervisory system have been adopted (i.e., the degree of independence of supervisory agency, the effectiveness of onsite and off-site examinations of banks by supervisory agency, and whether all banks are subject to supervision or not), with a higher score associated with better regulation and supervision. Each subindex is coded on a four-point scale, and is normalized between zero and one. In each category, a higher score corresponds to more advanced reforms. Greater details on the index are in Abiad, Detragiache and Tressel (2008).

As shown in Figure 1, the financial reform index has a general upward trend that accelerated during the 1990s and slowed down after 2000. Advanced countries have higher values of the index than developing countries throughout the sample period, indicating that credit markets have been and continue to be more liberalized in these countries. Nonetheless, significant reforms occurred in both groups of countries. In advanced countries, most of the progress with liberalization occurred during the 1980s, while in developing countries reforms accelerated after 1990.

\section{An overview of the data}

The baseline regression sample covers 85 countries over the period 1978-2005 (Table 1). Summary statistics are presented in Table 2. The private credit-to-GDP ratio ranges from below 5 percent of GDP for a small group of low-income countries (Albania, Algeria, Ethiopia, Ghana, Kyrgyz Republic, Nepal, Tanzania and Uganda) to above 160 percent for some advanced countries (Netherlands, Japan), indicating that there is enormous sample variation in the degree of financial depth. Some of this variation is cross-sectional, but there is also sizable time series variation, as many countries experienced considerable financial deepening over the sample period, as shown in Table 2.

Financial depth is significantly and positively correlated with the index of banking reforms and with other reform indices (securities markets, capital account, and international trade), suggesting that countries with deeper banking systems have a more liberalized banking sector, have done more reforms to develop securities markets, and have lower tariffs and a more open capital account regime (Table 3). ${ }^{16}$ In addition, financial depth is positively correlated with GDP per capita and with the fiscal balance, and negatively correlated with inflation, as expected.

As an initial exploration of the relationship between the banking reform index and financial depth in the sample, we perform a number of descriptive exercises.

A simple perspective on the data can be obtained by examining the behavior of private credit during episodes of intense banking sector reform. To this end, we define episodes of intense reform as changes in the index of 0.13 or more, which corresponds to the top quartile in the distribution of changes. Then, we average private credit across all the episodes of intense reform

\footnotetext{
${ }^{16}$ Correlations between the changes in these indices show that reforms, in general, do not occur simultaneously, even at a three-year frequency (Abiad, Detragiache and Tressel, 2008).
} 
in the years surrounding the reform. Figure 2 plots the results: on average, intense banking reform episodes are followed by a sizable deepening of the domestic banking system within countries, with the ratio of private credit to GDP increasing by about 10 percentage points over five years. Most of the effect occurs within the first three years of the reforms. Thus, reforms, at least major ones, seem to lead to an immediate upward spike in financial depth on average.

Figure 3 describes an alternative perspective on the data: it shows the evolution over time of the cross-sectional standard deviation of the banking reform index and the private credit-to-GDP ratio. Since the late 1980s, there has been a gradual decline in the cross-sectional dispersion of the banking reform index, indicating convergence in the degree of domestic financial liberalization across countries. On the other hand, there has been a steady increase in the crosssectional dispersion of financial depth, indicating that there has been no convergence (and even a divergence) across countries in financial depth. This seems to indicate that financial liberalization may not have much of an impact on financial deepening on average in the complete sample of countries, and that other factors may have been at work to offset, or prevent the pull toward convergence exercised by the liberalization process.

Figure 4 provides further evidence pointing in the same direction: while there is a positive cross-sectional correlation between the depth of the banking sector and the degree of banking sector liberalization in every year of the sample period, this correlation has decreased steadily since the early 1990s (Figure 3). As shown in Figure 1, financial sector reforms accelerated in many countries in the early 1990s, in particular in emerging markets and other developing countries. Thus, while reforms accelerated, the relationship between the degree of liberalization and financial depth seemed to weaken.

In the next sections, we explore these issues more rigorously using our empirical model.

\section{ESTIMATION RESULTS}

\section{The baseline model}

Table 4 presents estimation results for two versions of the dynamic auto-regressive distributed lag model presented in Section II above. The first version uses a maximum lag of two periods, while the second version extends the lag length to five periods. Control variables include the inflation rate and the log of GDP per capita with the same lag structure as the banking reform index. ${ }^{17}$ Each model is estimated for the entire sample and for separate subsamples for industrialized and developing countries. ${ }^{18}$

\footnotetext{
${ }^{17}$ We also estimated the model with lags length between 2 and 5, and up to 7 lags. The stylized facts emerging from this exercise are robust to changes in lag length.

${ }^{18}$ Alternatively, we could have dealt with possible sample heterogeneity by interacting group dummies with the variables of interest, but given the many lags in these variables this would have become unwieldy.
} 
Estimation results show that banking sector reforms are associated with an increase in the ratio of private credit to GDP in the two years following reforms. This result in consistent with the evidence in Figure 2, suggesting that following reform the banking sector becomes deeper. The magnitude of the impact of banking reforms is almost twice as large in developing countries as it is in more advanced countries, and the direct and indirect effects at a two-year horizon (the "long run" in this specification) is not significantly different from zero in the sample including only advanced countries. As for the control variables, as expected we find that an increase in inflation is followed by a reduction in the depth of the banking system, while an increase in GDP per capita is associated with banking system deepening.

Interestingly, when the maximum number of lags is increased to five years, thereby allowing us to investigate the effects of reforms on private credit at a longer horizon, the picture changes somewhat. In advanced countries, the effect of reforms on financial development is not significantly different from zero at impact, but is significant and positive at a five-year horizon. The opposite happens in developing countries: at the two-year horizon, banking reforms are strongly and positively associated with an increase in financial depth, but the impact of a banking reform becomes insignificantly different from zero after five years. ${ }^{19}$

To summarize, the relationship between financial liberalization and financial deepening seems to differ across various groups of countries. In advanced countries, reforms aimed at developing the banking sector seem to have a significant positive impact on our measure of financial depth, the ratio of private credit to GDP. In contrast, in developing countries, there is a sizable effect at a two-year horizon, but the impact seems to peter out later on, and it is no longer statistically significant at a five-year horizon. In the next section, we will try to explore which factors may account for this heterogeneity.

\section{Exploring further: crises, macroeconomic policies, and institutional differences}

Table 5 explores potential explanations for the heterogeneity in the effect of banking reforms that we have uncovered in Table 4. The results show that the presence of extreme observations, banking crises, bad policies, or non-linearities do not seem to account for the observed heterogeneity. ${ }^{20}$

More specifically, in the regressions in the first two columns Table 5, Panel A we exclude from the sample observations corresponding to the $1^{\text {st }}$ and $99^{\text {th }}$ percentile of the distribution of the private credit-to-GDP ratio. The long-run effect of reforms on financial development remains insignificant. The same is the case if we exclude from the sample observations corresponding to a banking crisis (the year of inception and the following four years) (columns 3 and 4).

\footnotetext{
${ }^{19}$ The coefficient for the developing country sample is also insignificant when using a maximum lag of three years or four years. These results are also robust to controlling for the occurrence of banking crises and controlling for the size of the fiscal deficit.

${ }^{20}$ Moreover, excluding time dummies—-which may have absorbed the effect of reforms if they happened simultaneously_does not result in a significant relationship between reforms and financial depth in the full sample.
} 
Next, we investigate whether the lack of sustained effects of financial reforms may be due to differences in macroeconomic policies. In columns 5 and 6, we drop from the sample countries that experienced high inflation (above 40 percent) over the previous five years; in columns 7 and 8, high fiscal deficits (defined as fiscal deficits above the sample median). This suggests that the long-run effect of financial reforms remains insignificant even in countries that followed sound macroeconomic policies, suggesting that macroeconomic policies are not, in general, a key factor constraining the effectiveness of banking reforms.

Finally, we explore whether the effect of financial reforms is non-linear. There could be thresholds of liberalization below which reforms do not have a major impact on financial depth, or alternatively, there may be decreasing returns to the effects of reforms. For this purpose, we split the sample into observations for which the level of liberalization is above (respectively below) median and report the regression results in columns 9 (respectively 10). The effect of banking reforms remains insignificant in the two sub samples, suggesting that non-linearities do not explain the heterogeneity in the effect of reforms.

In the regressions of Panel B of Table 5, we explore whether heterogeneity in the effect of banking reforms is related to differences in institutions that are important for credit markets to function well. We explore four alternative institutional dimensions: (i) the degree to which the power of the executive is curbed by various checks and balances (columns 1 and 2); (ii) the degree to which creditor rights are protected in bankruptcy; (iii) the legal origin (common law versus civil law); and (iv) the quality of contract enforcement, measured by an index from the "Doing Business Database" of the World Bank. ${ }^{21}$

Interestingly, the estimated long-run coefficient for the reform index is not significant in any of the subsamples except for one: the subsample of observations for which the property rights index is above the median. In this subsample, the long-run effect of financial reforms on financial depth is positive and significant. ${ }^{22}{ }^{23}$ Moreover, the coefficient is larger and the statistical significance is stronger than in the sample containing only advanced countriessuggesting that the institutional dimension may be more appropriate than the distinction between industrialized countries and developing countries.

While "unbundling” institutions is very challenging, because different institutional features can only be measured through imperfect proxies and because institutions can be complementary, this result is consistent with the view that institutions that limit the power of the executive are

\footnotetext{
21 This index is not available for the earlier part of our sample period, so the index reflect differences in contract enforcement across countries at the end of our sample period.

${ }^{22}$ We checked that the lack of significance in various subsamples is not driven by the inclusion of the year dummies. If reforms tended to happen at the same time across countries, their effect could indeed be absorbed by the fixed effects.

${ }^{23}$ When considering the top quartile of countries in term of private contract enforcement, we also uncover a positive effect of banking reforms (see column 13).
} 
key to the long-run success of financial liberalization, while other institutional aspects, such as good creditor rights, contract enforcement, or legal origin do not seem to be binding constraints on the effectiveness of financial reforms. ${ }^{24}$

A possible explanation for the key role of constraints on the executive is that this variable proxies for the risk of expropriation by the state or by powerful groups. With few checks and balances on the executive power, risks of expropriation may be high. This, in turn, keeps returns on private investment low, so that a profit-oriented private banking system is not willing to extend much credit beyond loans to the state or to powerful groups. In addition, banks themselves may see some of their profits expropriated or diverted to powerful groups, even if they have been formally privatized or are no longer subject to financial repression. Thus, reforms to liberalize the banking sector may not result in a sustained expansion of private sector lending in countries with weak protection of property rights.

A mantra often repeated in recent years is that financial liberalization can work well only where effective prudential regulation and supervision of banks is in place. Can we find support for this conjecture? The Abiad, Detragiache, Tressel (2008) reform dataset also covers reforms to upgrade regulation and supervision (measuring these aspects well is admittedly difficult). To test whether having a good banking supervisory and regulatory framework is a sufficient condition for other banking reforms to stimulate financial development, we exclude the supervision subindex from the banking reform index and split the sample according to the quality of supervision as measured by the subindex. Results reported in columns (14) and (15) show that banking reforms do not boost banking system depth even in environments with good supervisory laws. Indeed, the "long-run” effect is barely significant at the 10 percent level, and the estimated point estimate is also significantly smaller (0.278) than when the sample is split along the property right dimension. This suggests that improving property rights for institutions may be more important to the success of financial liberalization than only upgrading bank regulation and supervision: improvements in the latter are likely to be ineffective when there is political interference.

Figure 5 plots, for each subsample, the estimated cumulative effect of a large reform (a 0.13 change in the index) on the private credit-to-GDP ratio, as well as confidence intervals. ${ }^{25}$ Based on our model, at a five-year horizon the private credit-to-GDP ratio would increase by about 30 percent in the countries with good property rights. For example, a typical country with an initial private credit-to-GDP ratio of 33 percent (as shown in Figure 4) would end up with a private credit-to-GDP ratio of 44 percent after five years following a reform. This is the same order of magnitude as in the simple event study of Figure 2. On the contrary, in countries with

\footnotetext{
${ }^{24}$ Claessens and Laeven (2003) find that a high degree of protection of property rights is associated with faster growth in sectors in which firms allocate more investment to intangible assets. Tressel (2008) finds that financial reforms are more effective in stimulating the growth of sectors that are more dependent on external finance in countries that have a good protection of property rights.

${ }^{25} 0.13$ corresponds to the cut-off point for the top 5 percent observations of the distribution of changes in the normalized banking reform index. There are 123 reform episodes during which the normalized banking reform index changed by 0.13 or more.
} 
weak political institutions the estimated effect is close to zero at a five-year horizon, with a large error band.

\section{Robustness and falsification tests}

Next, we analyze the robustness of the positive relationship between financial development and reforms in the sample of countries with strong constraints on the executive (Table 6). In the first column, we restrict the sample further, to countries with good property rights and classified as developing. Interestingly, we find that financial sector reforms do increase financial depth at a five-year horizon also within this narrower sample. Thus, it seems that reforms succeed in developing countries, provided that political institutions are well developed.

Next, we replace our proxy for property rights with an alternative measure, the ICRG-Political Risk Services index of protection against expropriation used by Knack and Kiefer (1995) and by Acemoglu and Johnson (2005). The results are unchanged, suggesting that interpreting "constraints on the executive" as a proxy for protection from expropriation is reasonable. In the third column of Table 6, we exclude periods during which countries experienced internal or external conflicts - an extreme form of weak political institutions. Again, we find a significant effect of reforms on financial depth. ${ }^{26}$ The results are also robust to excluding observations with a very large increase in private credit (exceeding 20 percentage points of GDP in one year) and to controlling for fiscal policy.

Finally, we want to ensure that our results do not merely capture the impact of other omitted reforms. For this, we add to the baseline regression measures of reforms in areas other than domestic banking sector liberalization: securities market reforms, trade liberalization (proxied by the average tariff rate), and capital account liberalization (measured by an index of capital account restrictions on financial credits). While ensuring that our results do not reflect omitted reforms, these tests also help address the issue of possible selection bias: if the positive correlation between banking reforms and financial development was due to the fact that reforms are more likely when an economy is doing well, we should observe a positive and significant correlation between other reforms and financial deepening. In other words, these alternative reforms can be seen as "placebo" reform measures and provide a falsification test that seems to rule out the possibility that our results may be spurious. As shown in the table, the baseline model easily passes this falsification test: other reform indicators are not only insignificant but also barely affect the significance and the size of the effect of the banking reform index.

\section{GMM and instrumental variable estimation}

As discussed above, OLS estimates may be biased because of the presence of a lagged dependent variable and endogeneity of the regressors. To address these problems, we perform additional robustness tests using GMM estimators reported in Table 7. We primarily report estimations based on the system-GMM estimator, which is more appropriate when the country

\footnotetext{
${ }^{26}$ We used the ICRG indices of internal and external conflicts and, for each index, excluded observations below the sample median.
} 
dimension is small, but as a further robustness test we also estimate the model using difference $\mathrm{GMM}^{27}$ We find that the long-run effect of banking sector reforms remains positive and significant in almost all cases, and the magnitude is not very different from that of the OLS estimations (the magnitude, however, falls when using the difference estimator instead of the system GMM). ${ }^{28}$

The estimated impact of banking reforms may also be biased if reforms are more likely to occur in countries doing well and expecting an expansion of the banking sector's depth. As discussed above, this selection bias should be partly reduced to the extent that measures of other reforms (securities market, capital account, or trade liberalization) are not significant when included in the regression. However, it could be possible that the process that causes banking reforms may be different from that of other reforms. Moreover, the condition of the banking sector itself may affect the decision to reform while not affecting other reforms such as those of securities markets or the capital account.

For these reasons, in addition to the GMM regressions discussed above we develop an instrumental variable strategy to address a potential endogeneity bias. The hypothesis for the choice of instruments is that economic reforms diffuse across countries with close political ties as a result of learning or of an imitation process. Thus, we use as an instrument for domestic banking reforms the banking reform process of political allies weighted by the "Entente Alliances" index. This index takes a value of 0 or 1 whenever two countries are common members of, or signatories to, an entente or alliance in any given time period. ${ }^{29}$ The conjecture is that a country is more likely to adopt reform policies when political allies have already successfully implemented similar policies.

Our instrumental variable estimation is performed on a five-year period panel instead of with annual data and is based on equation (4). Given that we have already established our main result that the effect of banking reform on financial development is persistent only in countries with good property right institutions, we do not risk to miss any effect of reforms at this stage. We instrument both the change in the banking reform index over the five-year period $\Delta I_{i, t, t-5}$ and the index at the beginning of the five-year period $I_{i, t-5}$. The instruments are the changes in each of five subindices of the banking reform index of political allies over the same period $\left(\Delta I_{\text {pol, }, t,-5}^{k}\right.$ ), of the previous five-year period $\left(\Delta I_{\text {pol,t-5,t-10 }}^{k}\right)$, and the level of the subindices of the beginning of the period $\left(I_{\text {pol,t-5 }}^{k}\right)$ and of the previous period $\left(I_{\text {pol,t-10 }}^{k}\right)$ - where $I^{k}$ is the

\footnotetext{
${ }^{27}$ Tests or serial correlation are reported and confirm the validity of the identification assumptions. The Sargan test of overidentifying restrictions, not reported, has been shown to overreject in presence of heteroskedasticity and its distribution is known only with homoskedastic error terms (Arellano and Bond, 1991)

${ }^{28}$ The coefficient is slightly below 10 percent significance when we control for the average tariff index.

${ }^{29}$ The index is from Rajan and Subramanian (2005). The original source is the Correlates of War Database.
} 
subindex $k$ of the banking reform index (see the description of the financial reform data in Section III).

Therefore the first stage regressions of the Two Stage Least Square estimation are the following (only the excluded instruments are reported):

$$
\left\{\begin{array}{l}
\Delta I_{i, t, t-5}=\sum_{k} \delta_{k} \cdot \Delta I_{p o l, t, t-5}^{k}+\sum_{k} \eta_{k} \cdot I_{p o l, t-5}^{k}+\sum_{k} \delta_{k}^{\prime} \cdot \Delta I_{p o l, t-5, t-10}^{k}+\sum_{k} \eta_{k}^{\prime} \cdot I_{p o l, t-10}^{k}+v_{i t} \\
I_{i, t-5}=\sum_{k} \rho_{k} \cdot \Delta I_{p o l, t, t-5}^{k}+\sum_{k} \theta_{k} \cdot I_{p o l, t-5}^{k}+\sum_{k} \rho_{k}^{\prime} \cdot \Delta I_{p o l, t-5, t-10}^{k}+\sum_{k} \theta_{k}^{\prime} \cdot I_{p o l, t-10}^{k}+\varsigma_{i t}
\end{array}\right.
$$

Identification is based on the exclusion restrictions that levels and changes of the subindices of political allies are uncorrelated with unobserved factors affecting domestic financial development (conditional on other control variables). This is a reasonable assumption as it is unlikely that reforms undertaken in other countries with close political ties significantly affect the state of the domestic financial system other than through the reform process itself. Formally, the exclusion restrictions are:

$$
\left\{\begin{array}{l}
E\left(\Delta I_{p o l, t, t-5}^{k}, \omega_{i t}\right)=0, E\left(\Delta I_{p o l, t-5, t-10}^{k}, \omega_{i t}\right)=0 \\
E\left(I_{p o l, t-5}^{k}, \omega_{i t}\right)=0, E\left(I_{p o l, t-10}^{k}, \omega_{i t}\right)=0
\end{array}\right.
$$

Table 8 reports both OLS and 2SLS regressions based on a non-overlapping panel of five-year periods. The first three columns confirm the results obtained with the annual data. The effect of financial reforms on financial development is significant in countries with stronger constraints on the executive but is insignificant in other countries. Instrumental variable regressions confirm these results. Note that the estimated impact of domestic banking reforms in countries with good political institutions is now much larger than previously estimated: the OLS regressions predict a "long-run" coefficient of 2.31 and the IV regressions a coefficient of 2.74, while the annual regressions predicted a coefficient of 1.32 at a five-year horizon. This suggests the presence of an attenuation bias in OLS estimates.

Specification tests confirm the validity of our instruments. The null hypothesis of joint validity of the instruments (Hansen J test) is not rejected at the 18 percent level in the good property right sample. Moreover, the $\mathrm{F}$ tests of the first stage confirm that our instruments are reasonably strong. With the exception of the regression on the full sample, the F tests are above or close to the threshold of 10 recommended by Staiger and Stock (1997) to ensure that results are not biased by weak instrument problems, under the criterion that the bias of the IV regression is less than 10 percent of the bias of the OLS regression.

We also report OLS and 2SLS regressions on the full sample in which the banking reform index is interacted with the index of constraints on the executive. Overall results support the view that banking reforms are effective in stimulating financial development only in countries with sufficiently well-developed political institutions. 


\section{Sorting out the effects of different reforms}

By using an aggregate index of financial reforms, we are implicitly treating financial liberalization as a package. In practice, reforms in different areas may have different effects on financial development. For this reason, we break down the index of financial reforms into its five subcomponents and enter each component in the regression one at a time. As before, we restrict our analysis to the sample of countries with good property rights, where reforms have a significant, long-lasting effect on financial development. We also report regressions for the subset of non-advanced countries with good property rights. ${ }^{30}$ Abiad, Detragiache and Tressel (2008) show that the correlation among changes in the subindices is low, suggesting that we may be able to identify the effects of each area of reform on the process of financial deepening.

The results are in Table 9. Reforms that remove restrictions on credit allocation, lower reserve requirements or remove limits on credit growth, have a positive, significant, and long-lasting effect on private credit. So do reforms that facilitate entry into the banking system (including through foreign entry) and facilitate geographical expansion through the removal of branching restrictions, especially in developing countries. Bank privatization stimulates financial development, but not in the subset of developing countries. Measures to liberalize interest rates and strengthen bank supervision and regulation do not have a significant effect at a five-year horizon, while improvements in banking supervision and regulation tend to reduce financial development at impact. These results need to be interpreted with caution, since reforms in different areas may also be complementary.

\section{Conclusions}

In this paper we have tested whether the widespread reforms undertaken by most countries around the world to dismantle financial repression and expand the role of competition and free market forces in banking have resulted in financial deepening, as was intended. Our investigation has benefited from a newly available database that carefully records financial sector reforms in 91 countries during 1973-2005.

After conducting tests based on alternative empirical approaches and undertaking extensive robustness tests, we conclude that the beneficial effects of reforms on financial deepening have materialized only where the institutional environment was sufficiently favorable. More specifically, the key binding institutional dimension seems to have been the extent to which political institutions protect citizens from expropriation from the state or powerful elites. We do not find much evidence that other institutional dimensions, such as contractual rights, or features of the macroeconomic environment, such as fiscal prudence played such a pivotal role in shaping the impact of banking sector reforms. In addition, we do not find evidence that the

\footnotetext{
${ }^{30}$ When we estimate this regression in the sample of countries with weak property rights, we find that none of the components of the reform index is significant. This indicates that lack of significance for the overall index in this subsample is not due to the fact that different elements of reform have significant effects that work in opposite directions.
} 
response of bank credit to reforms was more positive where bank supervision and regulation were, on paper, stronger.

These findings are consistent with existing evidence that institutions protecting property rights have robust positive effects on financial development, investment, and growth, while contracting institutions do not (Acemoglu and Johnson, 2005). They indicate that financial sector reforms work best where political institutions, that protect private citizens from expropriation, are in place. Thus, political and financial sector reforms are strongly complementary.

How can these results be interpreted? One possibility is that in countries where expropriation is easy, financial reforms reduce the role of the state in the financial sector only on paper, while powerful elites continue to be able to divert financial resources to their own benefit, ultimately undermining the effectiveness of market mechanisms. Also, in these countries private sector business initiatives from groups that are not politically powerful may be constantly threatened with expropriation by the more powerful groups. As a result, such initiatives may not find financing from banks even if they are economically viable and even if banks are efficient and operate according to sound business principles. Thus, with weak property rights protection, privatized banks operating in a competitive market may be able to lend profitably only to wellconnected groups or to the government. 


\section{References}

Abiad, Abdul, and Ashoka Mody, 2005, "Financial Liberalization: What Shakes It? What Shapes It?”, American Economic Review, Vol. 95, pp. 66-88.

Abiad, Abdul, Enrica Detragiache, and Thierry Tressel, 2008, “A New Database of Financial Reforms,” forthcoming Working Paper, International Monetary Fund.

Abiad, Abdul, Nienke Oomes, and Kenichi Ueda, 2008, “The Quality Effect: Does Financial Liberalization Improve the Allocation of Capital?” Journal of Development Economics, Vol. 87 (2), pp. 270-82, October.

Acemoglu, Daron, and Simon Johnson, 2005, “Unbundling Institutions,” Journal of Political Economy, Vol. 113, pp. 949-95.

Acemoglu, Daron, Simon Johnson, and Pablo Querubin, 2008, “When Does Policy Reform Work? The Case of Central Bank Independence,” Brookings Paper on Economic Activity, forthcoming.

Agça, Senay, Gianni De Nicolo’, and Enrica Detragiache, 2008, “Financial Reforms, Globalization, and Corporate Leverage: International Evidence,” Unpublished, International Monetary Fund.

Arellano, Manuel, and Stephen R. Bond, 1991, "Some Tests of Specification for Panel Data: Monte Carlo Evidence and an Application to Employment Equations," Review of Economic Studies, Vol. 58, pp. 277-97.

Arellano, Manuel, and Olympia Bover, 1995, “Another Look at the Instrumental Variable Estimation of Error-Components Models,” Journal of Econometrics Vol. 68, pp. 29-52.

Attanasio, Orazio P., Picci Lucio, and Antonello E. Sorcu, 2000, “Savings, Growth, and Investment: A Macroeconomic Analysis Using a Panel of Countries,” Review of Economics and Statistics, Vol. 82, pp. 182-211.

Baltagi, Bati H., Panicos O. Demetriades, and Siong Hook Law, 2007, “Financial Development, Openness and Institutions: Evidence from Panel Data,” Working Paper No. 0022, Birbeck College.

Bertrand, Marianne, Antoinette Schoar, and David Thesmar, 2007, “Banking Deregulation and Industry Structure: Evidence from the 1985 French Banking Act,” Journal of Finance, Vol. 62, pp. 597-628.

Boyd, John H., Ross Levine, and Bruce D. Smith, 2001, “The Impact of Inflation on Financial Sector Performance,” Journal of Monetary Economics, Vol. 47, pp. 221-48. 
Braun, Matías, and Claudio Raddatz, 2008, “The Politics of Financial Development. Evidence from Trade Liberalization,” The Journal of Finance Vol. 63 (3), pp. 1469-1508.

Cetorelli, Nicola, and Philip E. Strahan, 2006, “Finance as a Barrier to Entry: Bank Competition and Industry Structure in Local U.S. Markets,” Journal of Finance, Vol. 61, No. 1, pp. 437-61.

Chinn, Menzie D., and Ito H., 2006, “Capital Account Liberalization, Institutions, and Financial Development: Cross Country Evidence,” Journal of Development Economics, Vol. 66, pp. 465-504.

Claessens, Stijn, and Luc Laeven, 2003, "Financial Development, Property Rights, and Growth,” Journal of Finance, Vol. 58, pp. 2401-436.

Demirgüç-Kunt and Enrica Detragiache, 1999, “Financial Liberalization and Financial Fragility,” in Boris Pleskovic and Joseph E. Stiglitz (Eds.) Annual World Bank Conference on Development Economics 1998, (The World Bank, Washington, DC).

Detragiache, Enrica, Thierry Tressel, and Poonam Gupta, 2008, "Foreign Banks in Poor Countries: Theory and Evidence,” Journal of Finance, Vol. 63, pp. 2123-160.

Djankov, Simeon, McLiesh, Caralee, and Andrei Shleifer, 2007, "Private Credit in 129 Countries,” Journal of Financial Economics, Vol. 84, pp. 299-329.

Galindo, Arturo, Fabio Schiantarelli, and Andrew Weiss, 2007, “Does Financial Liberalization Improve the Allocation of Investment? Micro Evidence from Developing Countries," Journal of Development Economics, Vol. 83, pp. 562-87.

Guiso, Luigi, Paola Sapienza, and Luigi Zingales, 2006, “The Cost of Banking Regulation,” NBER Working Paper No. 12501.

Chari, Anusha, and Peter Henry, 2008, "Firm-Specific Information and the Efficiency of Investment,” Journal of Financial Economics, 87(3), pp. 636-655.

Hauner, David, 2008, “Public Debt and Financial Development,” Journal of Development Economics, forthcoming.

International Monetary Fund, 2008, "Structural Reforms and Economic Performance in Advanced and Developing Countries,” paper prepared by the Research Department of the International Monetary Fund.

Jayaratne, Jith, and Philip E. Strahan, 1996, “The Finance-Growth Nexus: Evidence from BankBranch Deregulation,” Quarterly Journal of Economics, Vol. 108, pp. 717-38.

Kaminsky, Graciela, and Sergio L. Schmukler, 2003, “Short-Term Pain, Long-Run Gain: The Effects of Financial Liberalization,” NBER Working Paper No. 9787. 
Knack, Stephen and Philip Keefer, 1995, “Institutions and Economic Performance: Cross Country Tests using Alternative Measures,” Economics and Politics, Vol. 7, pp. 207-27.

La Porta, Rafael, Florencio Lopez-de-Silanes, Andrei Shleifer, and Robert Vishny, 1998, “Law and Finance,” Journal of Political Economy Vol. 106, pp. 1113-155.

La Porta, Rafael, Fernando Lopez de Silanes, and Andrei Shleifer, 2002, "Government Ownership of Commercial Banks,” Journal of Finance, Vol. 57, No.1, pp. 265-301.

Levine, Ross, 1997, "Financial Development and Economic Growth: Views and Agenda," Journal of Economic Literature, Vol. 35, No. 2, pp.688-726.

Levine, Ross, 2005, “Law, Endowments and Property Rights,” Journal of Economic Perspectives, Vol.19, No. 3, pp. 61-88.

McKinnon, Ronald I., 1973, Money and Capital in Economic Development, (Washington DC: Brookings Institutions).

McKinnon, Ronald I., 1993, The Order of Economic Liberalization: Financial Control in the Transition to a Market Economy, (Baltimore: Johns Hopkins University Press).

Mendoza, Enrique and Marco Terrones, 2008, “An Anatomy of Credit Booms: Evidence from Macro Aggregates and Micro Data,” paper presented at the IMF Conference on Financial Cycles, Liquidity, and Securitization, April 2008.

Nickell, Stephen, 1981, “Biases in Dynamic Models with Fixed Effects,” Econometrica, Vol. 49, pp. 359-82.

Prasad, Eswar, Rajan, Raghuram, and Arvind Subramanian, 2007, "Foreign Capital and Economic Growth,” Brookings Papers on Economic Activity, Vol. 1, pp. 153-209.

Rajan, Raghuram and Luigi Zingales, 1998, “Financial Dependence and Growth,” American Economic Review, June, Vol.88, pp. 559-86.

Rajan, Raghuram, and Arvind Subramanian, 2005, “Aid and Growth: What Does Cross-Country Evidence Really Show?”, NBER Working Paper No. 11657.

Rajan, Raghuram, and Luigi Zingales, 2003, “The Great Reversals: The politics of Financial Development in the Twentieth Century,” Journal of Financial Economics, Vol. 69, pp. 5-50.

Roe, Mark, and Jordan Siegel, 2008, “Political Instability’s Impact on Financial Development,” Mimeo Harvard University, July 2008. 
Shaw, Edward S., 1973, Financial Deepening in Economic Development, (New York: Oxford University Press).

Staiger, Douglas, and James H. Stock, 1997, “Instrumental Variables Regressions with Weak Instruments,” Econometrica, Vol. 65, pp. 557-86.

Stiroh, Kevin J. and Philip E. Strahan, 2003, “Competitive Dynamics of Deregulation: Evidence from U.S. Banking,” Journal of Money, Credit and Banking, Vol. 35, pp. 801-28.

Tressel, Thierry, 2008, "Unbundling the Effects of Reforms," paper presented at the IMF Conference "On the Causes and Consequences of Structural Reforms,” February 2008. 
Table 1. Sample Countries

\begin{tabular}{llll}
\hline & & & \\
1 & Albania & 43 & Kazakhstan \\
2 & Algeria & 44 & Kenya \\
3 & Argentina & 45 & Korea \\
4 & Australia & 46 & Kyrgyz Republic \\
5 & Austria & 47 & Latvia \\
6 & Bangladesh & 48 & Lithuania \\
7 & Belgium & 49 & Madagascar \\
8 & Bolivia & 50 & Malaysia \\
9 & Brazil & 51 & Mexico \\
10 & Bulgaria & 52 & Morocco \\
11 & Burkina Faso & 53 & Mozambique \\
12 & Cameroon & 54 & Nepal \\
13 & Canada & 55 & Netherlands \\
14 & Chile & 56 & New Zealand \\
15 & Colombia & 57 & Nicaragua \\
16 & Costa Rica & 58 & Nigeria \\
17 & Cote d'Ivoire & 59 & Norway \\
18 & Czech Republic & 60 & Pakistan \\
19 & Denmark & 61 & Paraguay \\
20 & Dominican Republic & 62 & Peru \\
21 & Ecuador & 63 & Philippines \\
22 & Egypt & 64 & Poland \\
23 & El Salvador & 65 & Portugal \\
24 & Estonia & 66 & Romania \\
25 & Ethiopia & 67 & Russia \\
26 & Finland & 68 & Senegal \\
27 & France & 69 & Singapore \\
28 & Georgia & 70 & South Africa \\
29 & Germany & 71 & Spain \\
30 & Ghana & 72 & Sri Lanka \\
31 & Greece & 73 & Sweden \\
32 & Guatemala & 74 & Switzerland \\
33 & Hong Kong & 75 & Tanzania \\
34 & Hungary & 76 & Thailand \\
35 & India & 77 & Tunisia \\
36 & Indonesia & 78 & Turkey \\
37 & Ireland & 79 & Uganda \\
38 & Israel & 80 & United Kingdom \\
39 & Italy & 81 & United States \\
40 & Jamaica & 82 & Uruguay \\
41 & Japan & & Venezuela \\
42 & Jordan & & \\
& & & \\
& & & \\
& & &
\end{tabular}


Table 2. Summary Statistics

\begin{tabular}{|c|c|c|c|c|c|}
\hline Variable & Number of Observations & Mean & Standard Deviation & Minimum & Maximum \\
\hline Private credit to GDP & 1744 & $42.00 \%$ & $35.10 \%$ & $1.10 \%$ & $200.70 \%$ \\
\hline Growth of private credit to GDP & 1744 & $2.10 \%$ & $12.60 \%$ & $-131.30 \%$ & $71.10 \%$ \\
\hline Index of banking reform & 1744 & 0.54 & 0.28 & 0 & 1 \\
\hline Change in banking reform index & 1744 & 0.02 & 0.05 & -0.27 & 0.33 \\
\hline \multicolumn{6}{|l|}{ Banking reform subindices: } \\
\hline Directed credit subindex & 1744 & 0.54 & 0.33 & 0 & 1 \\
\hline Interest rate subindex & 1744 & 0.71 & 0.4 & 0 & 1 \\
\hline Competition subindex & 1744 & 0.66 & 0.37 & 0 & 1 \\
\hline Supervision subindex & 1744 & 0.31 & 0.33 & 0 & 1 \\
\hline Privatisation subindex & 1744 & 0.48 & 0.39 & 0 & 1 \\
\hline Inflation & 1744 & $12.80 \%$ & $32.30 \%$ & $-9.80 \%$ & $1058.40 \%$ \\
\hline Log (GDP per capita) & 1744 & 8.7 & 1.1 & 5.9 & 10.5 \\
\hline Constraints on the Executive (Polity IV) & 1587 & 5.2 & 2.1 & 1 & 7 \\
\hline Creditor rights index & 1658 & 1.9 & 1.2 & 0 & 4 \\
\hline Common law dummy variable & 1744 & $34 \%$ & $47 \%$ & 0 & 1 \\
\hline Contract enforcement (days) & 1574 & 543.305 & 195.9692 & 120 & 980 \\
\hline General Government Balance to GDP & 1553 & $-3.10 \%$ & $4.60 \%$ & $-25.80 \%$ & $15.50 \%$ \\
\hline Securities market subindex & 1744 & 0.57 & 0.36 & 0 & 1 \\
\hline International capital flows subindex & 1744 & 0.63 & 0.35 & 0 & 1 \\
\hline Capital account index (Chinn \& Ito) & 1717 & 0.33 & 1.54 & -1.77 & 2.6 \\
\hline Average tariff index & 1602 & 0.15 & 0.13 & 0 & 1 \\
\hline
\end{tabular}


Table 3. Cross-Correlations

\begin{tabular}{|c|c|c|c|c|c|c|c|c|c|c|}
\hline & $\begin{array}{l}\text { Private } \\
\text { credit to } \\
\text { GDP }\end{array}$ & $\begin{array}{l}\text { Growth in } \\
\text { private } \\
\text { credit to } \\
\text { GDP }\end{array}$ & $\begin{array}{l}\text { Index of } \\
\text { Banking } \\
\text { Reforms }\end{array}$ & $\begin{array}{c}\text { Change in } \\
\text { Banking } \\
\text { Reform Index }\end{array}$ & nflation & $\begin{array}{l}\text { Log (GDP } \\
\text { per capita) }\end{array}$ & $\begin{array}{c}\text { Fiscal } \\
\text { balance to } \\
\text { GDP } \\
\end{array}$ & $\begin{array}{l}\text { Securities } \\
\text { Market } \\
\text { subindex } \\
\end{array}$ & $\begin{array}{c}\text { Capital } \\
\text { flows } \\
\text { subindex } \\
\end{array}$ & $\begin{array}{c}\text { Index of } \\
\text { average } \\
\text { tariff } \\
\end{array}$ \\
\hline $\begin{array}{l}\text { Private credit to } \\
\text { GDP }\end{array}$ & 1 & & & & & & & & & \\
\hline $\begin{array}{l}\text { Growth in private } \\
\text { credit to GDP }\end{array}$ & $\begin{array}{l}0.007 \\
0.761\end{array}$ & 1.000 & & & & & & & & \\
\hline $\begin{array}{l}\text { Index of banking } \\
\text { reforms }\end{array}$ & $\begin{array}{l}0.431 \\
0.000\end{array}$ & $\begin{array}{l}0.038 \\
0.078\end{array}$ & 1.000 & & & & & & & \\
\hline $\begin{array}{l}\text { Change in } \\
\text { Banking Reform }\end{array}$ & -0.086 & 0.007 & 0.112 & 1.000 & & & & & & \\
\hline Index & 0.000 & 0.748 & 0.000 & & & & & & & \\
\hline Inflation & $\begin{array}{r}-0.069 \\
0.001\end{array}$ & $\begin{array}{l}0.035 \\
0.111\end{array}$ & $\begin{array}{r}-0.083 \\
0.000\end{array}$ & $\begin{array}{l}0.091 \\
0.000\end{array}$ & 1.000 & & & & & \\
\hline $\begin{array}{l}\text { Log (GDP per } \\
\text { capita) }\end{array}$ & $\begin{array}{l}0.652 \\
0.000\end{array}$ & $\begin{array}{l}0.006 \\
0.784\end{array}$ & $\begin{array}{l}0.511 \\
0.000\end{array}$ & $\begin{array}{r}-0.009 \\
0.652\end{array}$ & $\begin{array}{r}-0.025 \\
0.214\end{array}$ & 1.000 & & & & \\
\hline $\begin{array}{l}\text { Fiscal balance to } \\
\text { GDP }\end{array}$ & $\begin{array}{l}0.205 \\
0.000\end{array}$ & $\begin{array}{l}0.068 \\
0.004\end{array}$ & $\begin{array}{l}0.325 \\
0.000\end{array}$ & $\begin{array}{l}0.013 \\
0.546\end{array}$ & $\begin{array}{r}-0.129 \\
0.000\end{array}$ & $\begin{array}{l}0.243 \\
0.000\end{array}$ & 1 & & & N \\
\hline $\begin{array}{l}\text { Securities market } \\
\text { index }\end{array}$ & $\begin{array}{l}0.553 \\
0.000\end{array}$ & $\begin{array}{l}0.040 \\
0.067\end{array}$ & $\begin{array}{l}0.738 \\
0.000\end{array}$ & $\begin{array}{l}0.011 \\
0.563\end{array}$ & $\begin{array}{r}-0.086 \\
0.000\end{array}$ & $\begin{array}{l}0.667 \\
0.000\end{array}$ & $\begin{array}{l}0.317 \\
0.000\end{array}$ & 1.000 & & \\
\hline $\begin{array}{l}\text { Capital flows } \\
\text { index }\end{array}$ & $\begin{array}{l}0.461 \\
0.000\end{array}$ & $\begin{array}{l}0.046 \\
0.033\end{array}$ & $\begin{array}{l}0.708 \\
0.000\end{array}$ & $\begin{array}{l}0.055 \\
0.006\end{array}$ & $\begin{array}{r}-0.086 \\
0.000\end{array}$ & $\begin{array}{l}0.542 \\
0.000\end{array}$ & $\begin{array}{l}0.245 \\
0.000\end{array}$ & $\begin{array}{l}0.676 \\
0.000\end{array}$ & 1 & \\
\hline & $\begin{array}{r}-0.385 \\
0.000\end{array}$ & $\begin{array}{r}-0.029 \\
0.223\end{array}$ & $\begin{array}{r}-0.595 \\
0.000\end{array}$ & $\begin{array}{r}-0.023 \\
0.308\end{array}$ & $\begin{array}{l}0.044 \\
0.052\end{array}$ & $\begin{array}{r}-0.562 \\
0.000\end{array}$ & $\begin{array}{r}-0.253 \\
0.000\end{array}$ & $\begin{array}{r}-0.517 \\
0.000\end{array}$ & $\begin{array}{r}-0.559 \\
0.000\end{array}$ & 1.000 \\
\hline
\end{tabular}

p-values are in italics 
Table 4. Baseline Regression: Two Alternative Maximum Lags

\begin{tabular}{|c|c|c|c|c|c|c|}
\hline Sample: & $\begin{array}{l}(1) \\
\text { Full }\end{array}$ & $\begin{array}{c}(2) \\
\text { Advanced } \\
\end{array}$ & $\begin{array}{c}\text { (3) } \\
\text { Developing }\end{array}$ & $\begin{array}{l}(4) \\
\text { Full }\end{array}$ & $\begin{array}{c}\text { (5) } \\
\text { Advanced }\end{array}$ & $\begin{array}{c}(6) \\
\text { Developing }\end{array}$ \\
\hline Banking reform index (t-2) & $\begin{array}{c}0.095 * * * \\
{[0.032]}\end{array}$ & $\begin{array}{c}0.054^{*} \\
{[0.026]}\end{array}$ & $\begin{array}{l}0.092 * * \\
{[0.045]}\end{array}$ & & & \\
\hline Banking reform index (t-5) & & & & $\begin{array}{r}0.054 \\
{[0.040]}\end{array}$ & $\begin{array}{l}0.056^{* *} \\
{[0.027]}\end{array}$ & $\begin{array}{c}0.023 \\
{[0.060]}\end{array}$ \\
\hline$\Delta$ Banking reform index & $\begin{array}{c}0.065 \\
{[0.063]}\end{array}$ & $\begin{array}{l}0.082 * \\
{[0.042]}\end{array}$ & $\begin{array}{c}0.063 \\
{[0.091]}\end{array}$ & $\begin{array}{c}0.067 \\
{[0.065]}\end{array}$ & $\begin{array}{c}0.071 \\
{[0.044]}\end{array}$ & $\begin{array}{c}0.072 \\
{[0.097]}\end{array}$ \\
\hline$\Delta$ Banking reform index $(\mathrm{t}-1)$ & $\begin{array}{c}0.210^{* * *} \\
{[0.053]}\end{array}$ & $\begin{array}{c}0.058 \\
{[0.044]}\end{array}$ & $\begin{array}{c}0.275^{* * *} \\
{[0.072]}\end{array}$ & $\begin{array}{c}0.130^{* *} \\
{[0.057]}\end{array}$ & $\begin{array}{c}0.021 \\
{[0.036]}\end{array}$ & $\begin{array}{l}0.181 * * \\
{[0.085]}\end{array}$ \\
\hline$\Delta$ Banking reform index $(\mathrm{t}-2)$ & & & & $\begin{array}{c}0.115^{* * * *} \\
{[0.043]}\end{array}$ & $\begin{array}{c}0.064 \\
{[0.038]}\end{array}$ & $\begin{array}{l}0.132 * \\
{[0.067]}\end{array}$ \\
\hline$\Delta$ Banking reform index $(\mathrm{t}-3)$ & & & & $\begin{array}{c}0.042 \\
{[0.057]}\end{array}$ & $\begin{array}{c}0.07 \\
{[0.056]}\end{array}$ & $\begin{array}{c}0.003 \\
{[0.079]}\end{array}$ \\
\hline$\Delta$ Banking reform index (t-4) & & & & $\begin{array}{c}0.057 \\
{[0.050]}\end{array}$ & $\begin{array}{c}0.066 \\
{[0.041]}\end{array}$ & $\begin{array}{c}0.048 \\
{[0.074]}\end{array}$ \\
\hline Log (private credit / GDP) (t-2) & $\begin{array}{c}-0.095^{* * *} \\
{[0.011]}\end{array}$ & $\begin{array}{c}-0.037 * * * \\
{[0.011]}\end{array}$ & $\begin{array}{c}-0.110^{* * *} \\
{[0.012]}\end{array}$ & & & \\
\hline Log (private credit / GDP) (t-5) & & & & $\begin{array}{c}-0.111^{* * *} \\
{[0.013]}\end{array}$ & $\begin{array}{c}-0.054^{* * *} \\
{[0.016]}\end{array}$ & $\begin{array}{c}-0.126^{* * *} \\
{[0.013]}\end{array}$ \\
\hline$\Delta \log$ (private credit / GDP) (t-1) & $\begin{array}{c}0.356^{* * *} \\
{[0.027]}\end{array}$ & $\begin{array}{c}0.520 * * * \\
{[0.041]}\end{array}$ & $\begin{array}{c}0.339 * * * \\
{[0.030]}\end{array}$ & $\begin{array}{c}0.385 * * * \\
{[0.037]}\end{array}$ & $\begin{array}{c}0.618^{* * * *} \\
{[0.053]}\end{array}$ & $\begin{array}{c}0.354 * * * \\
{[0.036]}\end{array}$ \\
\hline$\Delta \log$ (private credit / GDP) (t-2) & & & & $\begin{array}{c}-0.194 * * * \\
{[0.033]}\end{array}$ & $\begin{array}{c}-0.262^{* * *} \\
{[0.055]}\end{array}$ & $\begin{array}{c}-0.199 * * * \\
{[0.034]}\end{array}$ \\
\hline$\Delta \log$ (private credit / GDP) (t-3) & & & & $\begin{array}{c}0.002 \\
{[0.027]}\end{array}$ & $\begin{array}{l}0.134 * * \\
{[0.055]}\end{array}$ & $\begin{array}{c}-0.015 \\
{[0.027]}\end{array}$ \\
\hline$\Delta \log$ (private credit / GDP) (t-4) & & & & $\begin{array}{c}-0.077^{* * *} \\
{[0.023]}\end{array}$ & $\begin{array}{c}-0.108^{* *} \\
{[0.045]}\end{array}$ & $\begin{array}{c}-0.081^{* * *} \\
{[0.026]}\end{array}$ \\
\hline Inflation (t-2) & $\begin{array}{c}-0.005 \\
{[0.005]}\end{array}$ & $\begin{array}{c}-0.001 \\
{[0.005]}\end{array}$ & $\begin{array}{c}-0.005 \\
{[0.006]}\end{array}$ & & & \\
\hline Inflation (t-5) & & & & $\begin{array}{c}-0.042 * * \\
{[0.020]}\end{array}$ & $\begin{array}{c}-0.004 \\
{[0.006]}\end{array}$ & $\begin{array}{c}-0.068^{* * *} \\
{[0.018]}\end{array}$ \\
\hline$\Delta$ Inflation & $\begin{array}{c}-0.009 \\
{[0.006]}\end{array}$ & $\begin{array}{c}-0.016^{* * *} \\
{[0.005]}\end{array}$ & $\begin{array}{c}-0.009 \\
{[0.006]}\end{array}$ & $\begin{array}{c}-0.035^{* * *} \\
{[0.010]}\end{array}$ & $\begin{array}{l}-0.012 \\
{[0.008]}\end{array}$ & $\begin{array}{c}-0.045^{* * *} \\
{[0.013]}\end{array}$ \\
\hline$\Delta$ Inflation (t-1) & $\begin{array}{c}-0.005 \\
{[0.005]}\end{array}$ & $\begin{array}{c}0.01 \\
{[0.006]}\end{array}$ & $\begin{array}{c}-0.006 \\
{[0.006]}\end{array}$ & $\begin{array}{c}-0.096 * * * \\
{[0.017]}\end{array}$ & $\begin{array}{c}0.012 \\
{[0.011]}\end{array}$ & $\begin{array}{c}-0.117^{* * *} \\
{[0.019]}\end{array}$ \\
\hline$\Delta$ Inflation (t-2) & & & & $\begin{array}{c}-0.040^{* *} \\
{[0.020]}\end{array}$ & $\begin{array}{c}-0.013 \\
{[0.008]}\end{array}$ & $\begin{array}{c}-0.066 * * * \\
{[0.018]}\end{array}$ \\
\hline$\Delta$ Inflation (t-3) & & & & $\begin{array}{c}-0.042 * * \\
{[0.020]}\end{array}$ & $\begin{array}{c}0.023 \\
{[0.013]}\end{array}$ & $\begin{array}{c}-0.068^{* * *} \\
{[0.019]}\end{array}$ \\
\hline$\Delta$ Inflation (t-4) & & & & $\begin{array}{c}-0.042 * * \\
{[0.020]}\end{array}$ & $\begin{array}{c}-0.009 \\
{[0.010]}\end{array}$ & $\begin{array}{c}-0.068 * * * \\
{[0.018]}\end{array}$ \\
\hline
\end{tabular}


Table 4. Baseline Regression: Exploring Various Lag Structures (continued)

\begin{tabular}{|c|c|c|c|c|c|c|}
\hline Sample: & $\begin{array}{l}\text { (1) } \\
\text { Full }\end{array}$ & $\begin{array}{c}(2) \\
\text { Advanced }\end{array}$ & $\begin{array}{c}\text { (3) } \\
\text { Developing }\end{array}$ & $\begin{array}{l}\text { (4) } \\
\text { Full }\end{array}$ & $\begin{array}{c}\text { (5) } \\
\text { Advanced }\end{array}$ & $\begin{array}{c}(6) \\
\text { Developing }\end{array}$ \\
\hline Log (GDP per capita) (t-2) & $\begin{array}{c}0.126^{* * *} \\
{[0.023]}\end{array}$ & $\begin{array}{l}0.078^{* *} \\
{[0.028]}\end{array}$ & $\begin{array}{c}0.140 * * * \\
{[0.023]}\end{array}$ & & & \\
\hline Log (GDP per capita) (t-5) & & & & $\begin{array}{c}0.129 * * * \\
{[0.031]}\end{array}$ & $\begin{array}{l}0.059 * \\
{[0.032]}\end{array}$ & $\begin{array}{c}0.142 * * * \\
{[0.034]}\end{array}$ \\
\hline$\Delta \log ($ GDP per capita) & $\begin{array}{c}-0.02 \\
{[0.086]}\end{array}$ & $\begin{array}{l}-0.129 \\
{[0.143]}\end{array}$ & $\begin{array}{l}-0.023 \\
{[0.092]}\end{array}$ & $\begin{array}{l}-0.045 \\
{[0.087]}\end{array}$ & $\begin{array}{l}-0.273 \\
{[0.191]}\end{array}$ & $\begin{array}{c}-0.036 \\
{[0.091]}\end{array}$ \\
\hline$\Delta \log ($ GDP per capita) (t-1) & $\begin{array}{c}0.701^{* * * *} \\
{[0.072]}\end{array}$ & $\begin{array}{c}0.688 * * * \\
{[0.080]}\end{array}$ & $\begin{array}{c}0.697 * * * \\
{[0.079]}\end{array}$ & $\begin{array}{c}0.632 * * * \\
{[0.071]}\end{array}$ & $\begin{array}{c}0.782^{* * *} \\
{[0.121]}\end{array}$ & $\begin{array}{c}0.600^{* * *} \\
{[0.075]}\end{array}$ \\
\hline$\Delta \log ($ GDP per capita) (t-2) & & & & $\begin{array}{c}0.162 \\
{[0.107]}\end{array}$ & $\begin{array}{c}0.148 \\
{[0.152]}\end{array}$ & $\begin{array}{c}0.142 \\
{[0.115]}\end{array}$ \\
\hline$\Delta \log ($ GDP per capita) (t-3) & & & & $\begin{array}{c}0.266^{* * *} \\
{[0.061]}\end{array}$ & $\begin{array}{c}0.342 \\
{[0.209]}\end{array}$ & $\begin{array}{c}0.264^{* * *} \\
{[0.069]}\end{array}$ \\
\hline$\Delta \log ($ GDP per capita) (t-4) & & & & $\begin{array}{c}0.171^{* * *} \\
{[0.061]}\end{array}$ & $\begin{array}{l}-0.015 \\
{[0.173]}\end{array}$ & $\begin{array}{c}0.184^{* * *} \\
{[0.069]}\end{array}$ \\
\hline $\begin{array}{l}\text { Long-run effect-Banking } \\
\text { reform index }\end{array}$ & $\begin{array}{c}1.006 * * * \\
{[0.359]}\end{array}$ & $\begin{array}{c}1.465 \\
{[0.955]}\end{array}$ & $\begin{array}{c}0.840 * * * \\
{[0.403]}\end{array}$ & $\begin{array}{c}0.488 \\
{[0.372]}\end{array}$ & $\begin{array}{l}1.049 * \\
{[0.593]}\end{array}$ & $\begin{array}{c}0.179 \\
{[0.474]}\end{array}$ \\
\hline Observations & 2034 & 620 & 1414 & 1744 & 532 & 1212 \\
\hline R-squared & 0.43 & 0.54 & 0.44 & 0.49 & 0.61 & 0.5 \\
\hline
\end{tabular}

Regressions include country and year fixed effects and observations are clustered by country

Robust standard errors in brackets. ${ }^{* * *} \mathrm{p}<0.01,{ }^{* *} \mathrm{p}<0.05,{ }^{*} \mathrm{p}<0.1$ 
Table 5 Panel A. What explains the lack of sustained effect of reforms on financial depth in developing countries? Shocks, policies, non-linearities

\begin{tabular}{|c|c|c|c|c|c|c|c|c|c|c|}
\hline $\begin{array}{l}\text { Sample } \\
\text { Dropping : }\end{array}$ & $\begin{array}{c}\text { (1) } \\
\text { Full } \\
\text { Extreme valu } \\
\text { credit to }\end{array}$ & $\begin{array}{l}\text { (2) } \\
\text { Developing } \\
\text { es of private } \\
\text { DP ratio }\end{array}$ & $\begin{array}{l}\text { (3) } \\
\text { Full } \\
\text { Bankir }\end{array}$ & $\begin{array}{l}\quad \text { (4) } \\
\text { Developing } \\
\text { crisis }\end{array}$ & $\begin{array}{l}\text { (5) } \\
\text { Full } \\
\text { High i }\end{array}$ & $\begin{array}{l}\text { (6) } \\
\text { Developing } \\
\text { flation }\end{array}$ & $\begin{array}{l}\text { (7) } \\
\text { Full } \\
\text { High fis }\end{array}$ & $\begin{array}{c}\text { (8) } \\
\text { Developing } \\
\text { l deficit }\end{array}$ & $\begin{array}{c}\text { (9) } \\
\text { Above median } \\
\text { banking reform } \\
\text { index (t-5) }\end{array}$ & $\begin{array}{c}(10) \\
\text { Below median } \\
\text { banking reform } \\
\text { index (t-5) }\end{array}$ \\
\hline Banking reform index (t-5) & $\begin{array}{c}0.055 \\
{[0.040]}\end{array}$ & $\begin{array}{c}0.016 \\
{[0.061]}\end{array}$ & $\begin{array}{c}0.004 \\
{[0.044]}\end{array}$ & $\begin{array}{c}-0.06 \\
{[0.074]}\end{array}$ & $\begin{array}{c}0.038 \\
{[0.038]}\end{array}$ & $\begin{array}{c}0.011 \\
{[0.062]}\end{array}$ & $\begin{array}{c}0.084 \\
{[0.064]}\end{array}$ & $\begin{array}{c}-0.025 \\
{[0.090]}\end{array}$ & $\begin{array}{c}0.024 \\
{[0.159]}\end{array}$ & $\begin{array}{c}0.04 \\
{[0.065]}\end{array}$ \\
\hline$\Delta$ Banking reform index & $\begin{array}{c}0.066 \\
{[0.066]}\end{array}$ & $\begin{array}{c}0.068 \\
{[0.098]}\end{array}$ & $\begin{array}{c}0.045 \\
{[0.064]}\end{array}$ & $\begin{array}{c}0.032 \\
{[0.102]}\end{array}$ & $\begin{array}{c}0.068 \\
{[0.065]}\end{array}$ & $\begin{array}{c}0.061 \\
{[0.111]}\end{array}$ & $\begin{array}{c}-0.004 \\
{[0.086]}\end{array}$ & $\begin{array}{c}-0.085 \\
{[0.120]}\end{array}$ & $\begin{array}{c}-0.069 \\
{[0.122]}\end{array}$ & $\begin{array}{c}0.079 \\
{[0.082]}\end{array}$ \\
\hline$\Delta$ Banking reform index (t-1) & $\begin{array}{c}0.130 * * * \\
{[0.054]}\end{array}$ & $\begin{array}{c}0.170^{* * *} \\
{[0.078]}\end{array}$ & $\begin{array}{c}0.077 \\
{[0.054]}\end{array}$ & $\begin{array}{c}0.105 \\
{[0.086]}\end{array}$ & $\begin{array}{c}0.057 \\
{[0.053]}\end{array}$ & $\begin{array}{c}0.088 \\
{[0.090]}\end{array}$ & $\begin{array}{c}0.248 * * * \\
{[0.093]}\end{array}$ & $\begin{array}{c}0.258^{*} \\
{[0.129]}\end{array}$ & $\begin{array}{c}-0.097 \\
{[0.138]}\end{array}$ & $\begin{array}{l}0.128^{*} \\
{[0.068]}\end{array}$ \\
\hline$\Delta$ Banking reform index (t-2) & $\begin{array}{l}0.110^{* *} \\
{[0.045]}\end{array}$ & $\begin{array}{c}0.116 \\
{[0.069]}\end{array}$ & $\begin{array}{l}0.103^{*} \\
{[0.056]}\end{array}$ & $\begin{array}{c}0.122 \\
{[0.092]}\end{array}$ & $\begin{array}{l}0.105^{* *} \\
{[0.045]}\end{array}$ & $\begin{array}{c}0.131 \\
{[0.078]}\end{array}$ & $\begin{array}{c}0.096 \\
{[0.072]}\end{array}$ & $\begin{array}{c}0.01 \\
{[0.096]}\end{array}$ & $\begin{array}{c}0.117 \\
{[0.131]}\end{array}$ & $\begin{array}{c}0.091 \\
{[0.059]}\end{array}$ \\
\hline$\Delta$ Banking reform index (t-3) & $\begin{array}{c}0.036 \\
{[0.057]}\end{array}$ & $\begin{array}{l}-0.012 \\
{[0.079]}\end{array}$ & $\begin{array}{c}0.042 \\
{[0.058]}\end{array}$ & $\begin{array}{c}-0.023 \\
{[0.091]}\end{array}$ & $\begin{array}{c}0.039 \\
{[0.055]}\end{array}$ & $\begin{array}{c}0.012 \\
{[0.086]}\end{array}$ & $\begin{array}{c}0.112 * \\
{[0.064]}\end{array}$ & $\begin{array}{c}0.014 \\
{[0.093]}\end{array}$ & $\begin{array}{c}0.105 \\
{[0.115]}\end{array}$ & $\begin{array}{l}-0.017 \\
{[0.073]}\end{array}$ \\
\hline$\Delta$ Banking reform index (t-4) & $\begin{array}{c}0.059 \\
{[0.048]}\end{array}$ & $\begin{array}{c}0.041 \\
{[0.072]}\end{array}$ & $\begin{array}{c}0.019 \\
{[0.056]}\end{array}$ & $\begin{array}{c}0 \\
{[0.087]}\end{array}$ & $\begin{array}{c}0.026 \\
{[0.045]}\end{array}$ & $\begin{array}{c}0.017 \\
{[0.075]}\end{array}$ & $\begin{array}{c}0.021 \\
{[0.061]}\end{array}$ & $\begin{array}{c}-0.024 \\
{[0.086]}\end{array}$ & $\begin{array}{c}0.04 \\
{[0.131]}\end{array}$ & $\begin{array}{c}0.018 \\
{[0.079]}\end{array}$ \\
\hline Log (private credit / GDP) (t-5) & $\begin{array}{c}-0.109^{* * *} \\
{[0.013]}\end{array}$ & $\begin{array}{c}-0.123^{* * *} \\
{[0.012]}\end{array}$ & $\begin{array}{c}-0.088^{* * * *} \\
{[0.015]}\end{array}$ & $\begin{array}{c}-0.102 * * * \\
{[0.019]}\end{array}$ & $\begin{array}{c}-0.093 * * * \\
{[0.012]}\end{array}$ & $\begin{array}{c}-0.109 * * * \\
{[0.011]}\end{array}$ & $\begin{array}{c}-0.143^{* * *} \\
{[0.025]}\end{array}$ & $\begin{array}{c}-0.181^{* * *} \\
{[0.023]}\end{array}$ & $\begin{array}{c}-0.229 * * * \\
{[0.041]}\end{array}$ & $\begin{array}{c}-0.126^{* * *} \\
{[0.013]}\end{array}$ \\
\hline$\Delta \log$ (private credit / GDP) (t-1) & $\begin{array}{c}0.383^{* * *} \\
{[0.039]}\end{array}$ & $\begin{array}{c}0.349 * * * \\
{[0.038]}\end{array}$ & $\begin{array}{c}0.399 * * * \\
{[0.047]}\end{array}$ & $\begin{array}{c}0.366 * * * \\
{[0.050]}\end{array}$ & $\begin{array}{c}0.416 * * * \\
{[0.045]}\end{array}$ & $\begin{array}{c}0.382 * * * \\
{[0.044]}\end{array}$ & $\begin{array}{c}0.349 * * * \\
{[0.056]}\end{array}$ & $\begin{array}{c}0.302 * * * \\
{[0.056]}\end{array}$ & $\begin{array}{c}0.326 * * * \\
{[0.108]}\end{array}$ & $\begin{array}{c}0.345^{* * * *} \\
{[0.037]}\end{array}$ \\
\hline$\Delta \log$ (private credit / GDP) (t-2) & $\begin{array}{c}-0.209 * * * \\
{[0.034]}\end{array}$ & $\begin{array}{c}-0.211^{* * * *} \\
{[0.036]}\end{array}$ & $\begin{array}{c}-0.200 * * * \\
{[0.035]}\end{array}$ & $\begin{array}{c}-0.206 * * * \\
{[0.037]}\end{array}$ & $\begin{array}{c}-0.227 * * * \\
{[0.039]}\end{array}$ & $\begin{array}{c}-0.233 * * * \\
{[0.042]}\end{array}$ & $\begin{array}{c}-0.254 * * * \\
{[0.049]}\end{array}$ & $\begin{array}{c}-0.255^{* * *} \\
{[0.050]}\end{array}$ & $\begin{array}{c}-0.414 * * * \\
{[0.063]}\end{array}$ & $\begin{array}{c}-0.178 * * * \\
{[0.035]}\end{array}$ \\
\hline$\Delta \log$ (private credit / GDP) (t-3) & $\begin{array}{c}0.013 \\
{[0.029]}\end{array}$ & $\begin{array}{l}-0.002 \\
{[0.029]}\end{array}$ & $\begin{array}{c}0.032 \\
{[0.030]}\end{array}$ & $\begin{array}{c}0.013 \\
{[0.032]}\end{array}$ & $\begin{array}{c}0.004 \\
{[0.034]}\end{array}$ & $\begin{array}{c}-0.018 \\
{[0.031]}\end{array}$ & $\begin{array}{c}0.016 \\
{[0.050]}\end{array}$ & $\begin{array}{c}-0.02 \\
{[0.051]}\end{array}$ & $\begin{array}{c}0.01 \\
{[0.052]}\end{array}$ & $\begin{array}{l}-0.031 \\
{[0.029]}\end{array}$ \\
\hline$\Delta \log$ (private credit / GDP) (t-4) & $\begin{array}{c}-0.076^{* * *} \\
{[0.023]}\end{array}$ & $\begin{array}{c}-0.079 * * * \\
{[0.026]}\end{array}$ & $\begin{array}{c}-0.079 * * * \\
{[0.028]}\end{array}$ & $\begin{array}{c}-0.083^{* *} \\
{[0.032]}\end{array}$ & $\begin{array}{l}-0.033 \\
{[0.024]}\end{array}$ & $\begin{array}{c}-0.029 \\
{[0.027]}\end{array}$ & $\begin{array}{c}-0.143^{* * *} \\
{[0.034]}\end{array}$ & $\begin{array}{c}-0.173 * * * \\
{[0.036]}\end{array}$ & $\begin{array}{c}-0.233^{* * *} \\
{[0.072]}\end{array}$ & $\begin{array}{c}-0.067^{* *} \\
{[0.028]}\end{array}$ \\
\hline Long run effect & $\begin{array}{c}0.505 \\
{[0.384]}\end{array}$ & $\begin{array}{c}0.132 \\
{[0.490]}\end{array}$ & $\begin{array}{c}0.040 \\
{[0.499]}\end{array}$ & $\begin{array}{c}-0.589 \\
{[0.739]}\end{array}$ & $\begin{array}{c}0.405 \\
{[0.415]}\end{array}$ & $\begin{array}{c}0.104 \\
{[0.564]}\end{array}$ & $\begin{array}{c}0.592 \\
{[0.464]}\end{array}$ & $\begin{array}{c}-0.141 \\
{[0.498]}\end{array}$ & $\begin{array}{c}0.104 \\
{[0.695]}\end{array}$ & $\begin{array}{c}0.316 \\
{[0.504]}\end{array}$ \\
\hline $\begin{array}{l}\text { Observations } \\
\text { R-squared }\end{array}$ & $\begin{array}{c}1710 \\
0.5054\end{array}$ & $\begin{array}{c}1194 \\
0.5178\end{array}$ & $\begin{array}{c}1393 \\
0.5\end{array}$ & $\begin{array}{c}909 \\
0.51\end{array}$ & $\begin{array}{l}1485 \\
0.51\end{array}$ & $\begin{array}{l}964 \\
0.52\end{array}$ & $\begin{array}{l}774 \\
0.63\end{array}$ & $\begin{array}{l}533 \\
0.67\end{array}$ & $\begin{array}{l}532 \\
0.75\end{array}$ & $\begin{array}{l}1212 \\
0.48\end{array}$ \\
\hline
\end{tabular}

Note: all OLS regressions include country and year fixed effects, and the 5 lags of inflation and GDP per capita as control variables- sample is split using the median of the relevant variable, and dropping observations below the median. For banking crises and high inflation episodes, observations are dropped if an episode occured over the 5 year period Robust standard errors in brackets, observations are clustered by country, ***: $p<0.01, * *: p<0.05,{ }^{*}: \mathrm{p}<0.1$ 
Table 5 Panel B. What explains the lack of sustained effect of reforms on financial depth in developing countries?

Institutions

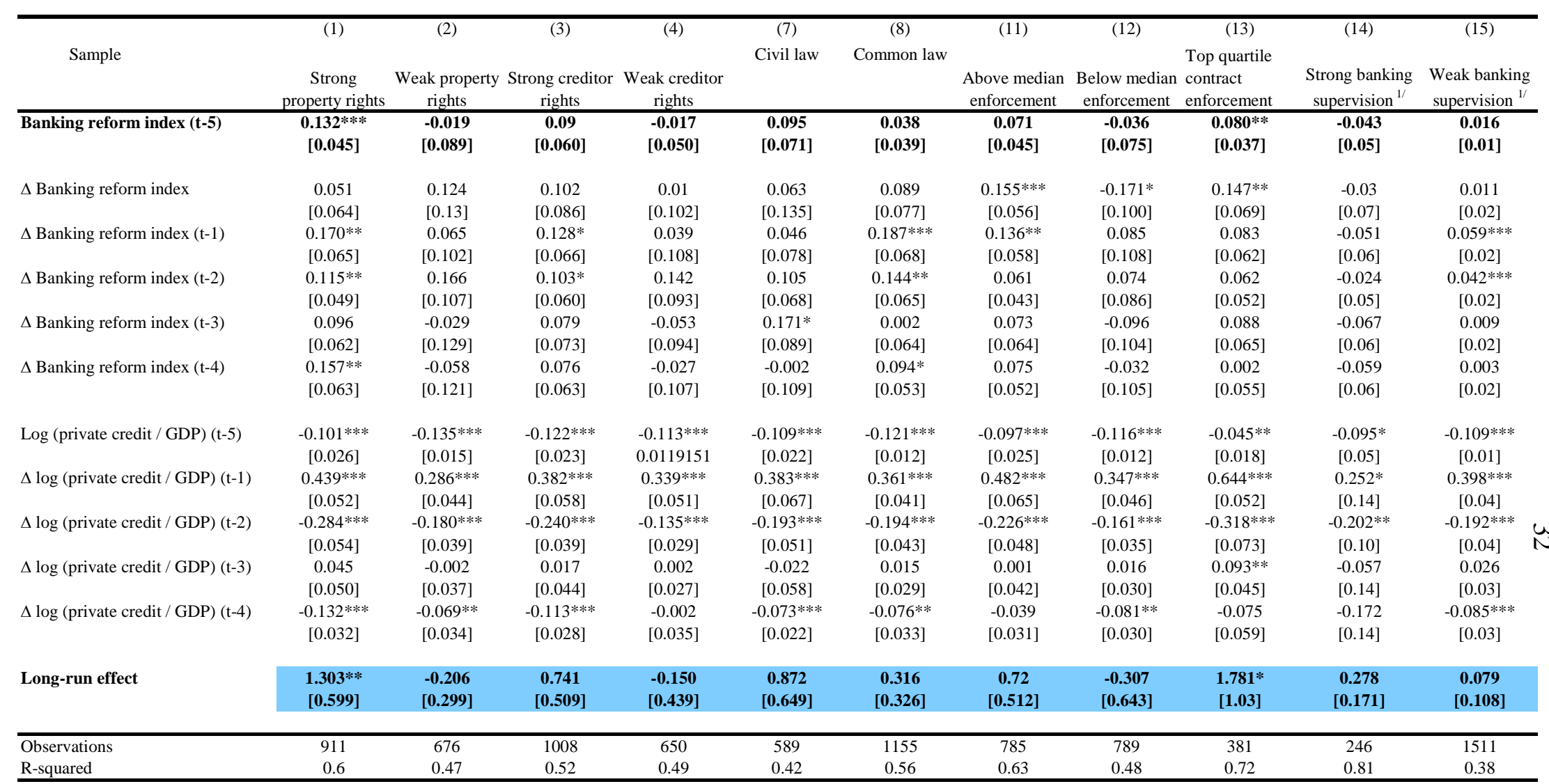

Note: all regressions include country and year fixed effects, the 5 lags of inflation and GDP per capita as control variables- sample is split using the median of the

relevant variable unless indicated.

${ }^{1 /}$ banking reform index excludes banking supervision subindex which is instead used to split the sample. Strong supervision group is country-year for which supervision index takes one of the two top values at date t5 , and weak supervision group is the complement.

Robust standard errors in brackets, observations are clustered by country, ***: $\mathrm{p}<0.01, * *: \mathrm{p}<0.05, *$ : $\mathrm{p}<0.1$ 
Table 6. Regressions countries with good property rights

Robustness test

\begin{tabular}{|c|c|c|c|c|c|c|c|c|}
\hline & \multirow[b]{3}{*}{ Only LDCs } & \multirow{3}{*}{$\begin{array}{l}\text { (2) } \\
\text { Above median } \\
\text { property rights } \\
\text { (IRIS-ICRG) }\end{array}$} & \multirow{3}{*}{$\begin{array}{l}\text { (3) } \\
\text { (1) + dropping } \\
\text { extreme private } \\
\text { credit to GDP }\end{array}$} & \multirow{3}{*}{$\begin{array}{l}\text { (4) } \\
\text { dropping political } \\
\text { instability episodes }\end{array}$} & (5) & (6) & (7) & (8) \\
\hline & & & & & \multicolumn{4}{|c|}{ Control variable: } \\
\hline & & & & & $\begin{array}{l}\text { Fiscal balance to } \\
\text { GDP }\end{array}$ & $\begin{array}{l}\text { Securities market } \\
\text { liberalization }\end{array}$ & $\begin{array}{c}\text { Capital account } \\
\text { liberalization }\end{array}$ & $\begin{array}{l}\text { Average tariff } \\
\text { index }\end{array}$ \\
\hline Banking reform index (t-5) & $\begin{array}{l}0.164 * \\
{[0.086]}\end{array}$ & $\begin{array}{l}0.162 * \\
{[0.088]}\end{array}$ & $\begin{array}{c}0.116 * * * \\
{[0.040]}\end{array}$ & $\begin{array}{l}0.103^{* *} \\
{[0.050]}\end{array}$ & $\begin{array}{c}0.194 * * * \\
{[0.048]}\end{array}$ & $\begin{array}{c}0.137^{* * *} \\
{[0.045]}\end{array}$ & $\begin{array}{l}0.121^{* *} \\
{[0.046]}\end{array}$ & $\begin{array}{l}0.157 * * \\
{[0.062]}\end{array}$ \\
\hline$\Delta$ Banking reform index & $\begin{array}{l}-0.053 \\
{[0.123]}\end{array}$ & $\begin{array}{c}0.085 \\
{[0.136]}\end{array}$ & $\begin{array}{c}0.031 \\
{[0.056]}\end{array}$ & $\begin{array}{c}0.053 \\
{[0.055]}\end{array}$ & $\begin{array}{c}0.035 \\
{[0.067]}\end{array}$ & $\begin{array}{c}0.051 \\
{[0.064]}\end{array}$ & $\begin{array}{c}0.05 \\
{[0.066]}\end{array}$ & $\begin{array}{c}0.038 \\
{[0.082]}\end{array}$ \\
\hline$\Delta$ Banking reform index (t-2) & $\begin{array}{c}0.105 \\
{[0.095]}\end{array}$ & $\begin{array}{c}0.065 \\
{[0.076]}\end{array}$ & $\begin{array}{c}0.109 * * \\
{[0.051]}\end{array}$ & $\begin{array}{c}0.05 \\
{[0.041]}\end{array}$ & $\begin{array}{l}0.130^{* *} \\
{[0.053]}\end{array}$ & $\begin{array}{l}0.115^{* *} \\
{[0.047]}\end{array}$ & $\begin{array}{l}0.102^{* *} \\
{[0.049]}\end{array}$ & $\begin{array}{c}0.1 \\
{[0.067]}\end{array}$ \\
\hline$\Delta$ Banking reform index (t-3) & $\begin{array}{c}0.104 \\
{[0.109]}\end{array}$ & $\begin{array}{c}0.193 * * * \\
{[0.060]}\end{array}$ & $\begin{array}{l}0.105^{*} \\
{[0.061]}\end{array}$ & $\begin{array}{c}0.058 \\
{[0.068]}\end{array}$ & $\begin{array}{l}0.132 * * \\
{[0.059]}\end{array}$ & $\begin{array}{c}0.098 \\
{[0.062]}\end{array}$ & $\begin{array}{c}0.08 \\
{[0.063]}\end{array}$ & $\begin{array}{c}0.106 \\
{[0.070]}\end{array}$ \\
\hline$\Delta$ Banking reform index (t-4) & $\begin{array}{l}0.265^{*} \\
{[0.146]}\end{array}$ & $\begin{array}{c}0.248 * * * \\
{[0.082]}\end{array}$ & $\begin{array}{l}0.146^{* *} \\
{[0.058]}\end{array}$ & $\begin{array}{c}0.055 \\
{[0.062]}\end{array}$ & $\begin{array}{c}0.202^{* *} \\
{[0.080]}\end{array}$ & $\begin{array}{l}0.158^{* *} \\
{[0.064]}\end{array}$ & $\begin{array}{l}0.146^{* *} \\
{[0.064]}\end{array}$ & $\begin{array}{l}0.173^{* *} \\
{[0.086]}\end{array}$ \\
\hline Log (private credit / GDP) (t-5) & $\begin{array}{c}-0.188^{* * *} \\
{[0.028]}\end{array}$ & $\begin{array}{c}-0.175^{* * *} \\
{[0.034]}\end{array}$ & $\begin{array}{c}-0.096 * * * \\
{[0.027]}\end{array}$ & $\begin{array}{c}-0.103 * * * \\
{[0.024]}\end{array}$ & $\begin{array}{c}-0.141 * * * \\
{[0.029]}\end{array}$ & $\begin{array}{c}-0.100 * * * \\
{[0.025]}\end{array}$ & $\begin{array}{c}-0.101 * * * \\
{[0.026]}\end{array}$ & $\begin{array}{c}-0.160 * * * \\
{[0.028]}\end{array}$ \\
\hline$\Delta \log$ (private credit / GDP) (t-2) & $\begin{array}{c}-0.315^{* * *} \\
{[0.067]}\end{array}$ & $\begin{array}{c}-0.242^{* * *} \\
{[0.090]}\end{array}$ & $\begin{array}{c}-0.267^{* * *} \\
{[0.057]}\end{array}$ & $\begin{array}{c}-0.275^{* * *} \\
{[0.053]}\end{array}$ & $\begin{array}{c}-0.297^{* * *} \\
{[0.062]}\end{array}$ & $\begin{array}{c}-0.286^{* * *} \\
{[0.053]}\end{array}$ & $\begin{array}{c}-0.286^{* * * *} \\
{[0.052]}\end{array}$ & $\begin{array}{c}-0.312 * * * \\
{[0.050]}\end{array}$ \\
\hline$\Delta \log$ (private credit / GDP) (t-3) & $\begin{array}{c}-0.038 \\
{[0.054]}\end{array}$ & $\begin{array}{c}-0.081 \\
{[0.072]}\end{array}$ & $\begin{array}{c}0.056 \\
{[0.049]}\end{array}$ & $\begin{array}{c}0.038 \\
{[0.045]}\end{array}$ & $\begin{array}{c}0.012 \\
{[0.048]}\end{array}$ & $\begin{array}{c}0.042 \\
{[0.051]}\end{array}$ & $\begin{array}{c}0.045 \\
{[0.048]}\end{array}$ & $\begin{array}{c}0.015 \\
{[0.052]}\end{array}$ \\
\hline$\Delta \log$ (private credit / GDP) (t-4) & $\begin{array}{c}-0.180^{* * *} \\
{[0.052]}\end{array}$ & $\begin{array}{l}-0.094 \\
{[0.059]}\end{array}$ & $\begin{array}{c}-0.126 * * * \\
{[0.033]}\end{array}$ & $\begin{array}{c}-0.124 * * * \\
{[0.033]}\end{array}$ & $\begin{array}{c}-0.140 * * * \\
{[0.043]}\end{array}$ & $\begin{array}{c}-0.135^{* * *} \\
{[0.034]}\end{array}$ & $\begin{array}{c}-0.131 * * * \\
{[0.029]}\end{array}$ & $\begin{array}{c}-0.135 * * * \\
{[0.040]}\end{array}$ \\
\hline Control variable (t-5) & . & . & . & . & $\begin{array}{c}0.001 \\
{[0.002]}\end{array}$ & $\begin{array}{c}-0.01 \\
{[0.025]}\end{array}$ & $\begin{array}{c}0.015 \\
{[0.021]}\end{array}$ & $\begin{array}{c}0.074 \\
{[0.072]}\end{array}$ \\
\hline$\Delta$ Control variable & . & . & . & . & $\begin{array}{c}0.002 \\
{[0.003]}\end{array}$ & $\begin{array}{l}-0.044 \\
{[0.036]}\end{array}$ & $\begin{array}{l}-0.013 \\
{[0.030]}\end{array}$ & $\begin{array}{l}-0.087 \\
{[0.089]}\end{array}$ \\
\hline$\Delta$ Control variable (t-1) & . & . & . & . & $\begin{array}{c}0.002 \\
{[0.003]}\end{array}$ & $\begin{array}{c}0.017 \\
{[0.029]}\end{array}$ & $\begin{array}{c}0.022 \\
{[0.019]}\end{array}$ & $\begin{array}{c}-0.018 \\
{[0.060]}\end{array}$ \\
\hline$\Delta$ Control variable $(\mathrm{t}-2)$ & . & . & . & . & $\begin{array}{c}0.005 \\
{[0.003]}\end{array}$ & $\begin{array}{c}0.009 \\
{[0.030]}\end{array}$ & $\begin{array}{c}0.028 \\
{[0.023]}\end{array}$ & $\begin{array}{c}0.043 \\
{[0.067]}\end{array}$ \\
\hline$\Delta$ Control variable $(\mathrm{t}-3)$ & . & . & . & . & $\begin{array}{l}0.003^{*} \\
{[0.002]}\end{array}$ & $\begin{array}{c}0.013 \\
{[0.030]}\end{array}$ & $\begin{array}{c}0.009 \\
{[0.018]}\end{array}$ & $\begin{array}{c}-0.03 \\
{[0.123]}\end{array}$ \\
\hline$\Delta$ Control variable $(\mathrm{t}-4)$ & . & . & . & . & $\begin{array}{c}0.003 \\
{[0.002]}\end{array}$ & $\begin{array}{c}0.007 \\
{[0.033]}\end{array}$ & $\begin{array}{c}0.024 \\
{[0.023]}\end{array}$ & $\begin{array}{c}0.133 \\
{[0.113]}\end{array}$ \\
\hline R-squared & 0.68 & 0.65 & 0.56 & 0.58 & 0.66 & 0.6 & 0.6 & 0.67 \\
\hline
\end{tabular}

ill regressions include country and year fixed effects, and the 5 lags of inflation and GDP per capita as control variables.

Robust standard errors in brackets, observations clustered by country, ${ }^{* * *} \mathrm{p}<0.01,{ }^{* *} \mathrm{p}<0.05,{ }^{*} \mathrm{p}<0.1$. 
34

Table 7. GMM regressions

\begin{tabular}{|c|c|c|c|c|c|c|}
\hline & \multirow[t]{3}{*}{ (1) } & \multirow[t]{2}{*}{$(2)$} & (3) & (4) & $(5)$ & (6) \\
\hline & & & \multicolumn{4}{|c|}{ control variable } \\
\hline & & $\begin{array}{l}\text { Difference } \\
\text { GMM }\end{array}$ & $\begin{array}{l}\text { Fiscal balance to } \\
\text { GDP }\end{array}$ & $\begin{array}{c}\text { securities market } \\
\text { liberalization }\end{array}$ & $\begin{array}{l}\text { International capital } \\
\text { flows subindex }\end{array}$ & $\begin{array}{l}\text { Average tariff } \\
\text { index }\end{array}$ \\
\hline Banking reform index (t-5) & $\begin{array}{c}0.059 * * * \\
{[0.021]}\end{array}$ & $\begin{array}{l}0.083 * \\
{[0.043]}\end{array}$ & $\begin{array}{l}0.036^{*} \\
{[0.022]}\end{array}$ & $\begin{array}{l}0.042 * * \\
{[0.021]}\end{array}$ & $\begin{array}{c}0.049 * * \\
{[0.022]}\end{array}$ & $\begin{array}{c}0.03 \\
{[0.022]}\end{array}$ \\
\hline$\Delta$ Banking reform index & $\begin{array}{c}0.074 \\
{[0.063]}\end{array}$ & $\begin{array}{c}0.029 \\
{[0.058]}\end{array}$ & $\begin{array}{c}0.01 \\
{[0.067]}\end{array}$ & $\begin{array}{c}0.047 \\
{[0.061]}\end{array}$ & $\begin{array}{c}0.054 \\
{[0.064]}\end{array}$ & $\begin{array}{c}0.055 \\
{[0.073]}\end{array}$ \\
\hline$\Delta$ Banking reform index (t-1) & $\begin{array}{c}0.194 * * * \\
{[0.055]}\end{array}$ & $\begin{array}{c}0.165^{* * *} \\
{[0.046]}\end{array}$ & $\begin{array}{l}0.160^{* *} \\
{[0.070]}\end{array}$ & $\begin{array}{c}0.167^{* * *} \\
{[0.055]}\end{array}$ & $\begin{array}{c}0.146^{* * *} \\
{[0.052]}\end{array}$ & $\begin{array}{l}0.164 * * \\
{[0.064]}\end{array}$ \\
\hline$\Delta$ Banking reform index (t-2) & $\begin{array}{l}0.087 * * \\
{[0.038]}\end{array}$ & $\begin{array}{l}0.098^{* *} \\
{[0.045]}\end{array}$ & $\begin{array}{l}0.060^{*} \\
{[0.031]}\end{array}$ & $\begin{array}{l}0.067 * * \\
{[0.034]}\end{array}$ & $\begin{array}{c}0.053 \\
{[0.036]}\end{array}$ & $\begin{array}{c}0.068 \\
{[0.042]}\end{array}$ \\
\hline$\Delta$ Banking reform index (t-3) & $\begin{array}{c}0.03 \\
{[0.065]}\end{array}$ & $\begin{array}{c}0.035 \\
{[0.062]}\end{array}$ & $\begin{array}{c}0.062 \\
{[0.048]}\end{array}$ & $\begin{array}{c}0.021 \\
{[0.057]}\end{array}$ & $\begin{array}{c}0.026 \\
{[0.055]}\end{array}$ & $\begin{array}{c}0.024 \\
{[0.057]}\end{array}$ \\
\hline$\Delta$ Banking reform index (t-4) & $\begin{array}{l}0.132^{* *} \\
{[0.059]}\end{array}$ & $\begin{array}{l}0.089^{*} \\
{[0.049]}\end{array}$ & $\begin{array}{c}0.082 \\
{[0.058]}\end{array}$ & $\begin{array}{c}0.088 \\
{[0.057]}\end{array}$ & $\begin{array}{l}0.100^{*} \\
{[0.056]}\end{array}$ & $\begin{array}{c}0.08 \\
{[0.055]}\end{array}$ \\
\hline Log (private credit / GDP) (t-5) & $\begin{array}{c}-0.045^{* * *} \\
{[0.009]}\end{array}$ & $\begin{array}{c}-0.208^{* * *} \\
{[0.032]}\end{array}$ & $\begin{array}{c}-0.043^{* * *} \\
{[0.008]}\end{array}$ & $\begin{array}{c}-0.046^{* * *} \\
{[0.009]}\end{array}$ & $\begin{array}{c}-0.044^{* * *} \\
{[0.008]}\end{array}$ & $\begin{array}{c}-0.046^{* * *} \\
{[0.009]}\end{array}$ \\
\hline$\Delta \log$ (private credit / GDP) (t-1) & $\begin{array}{c}0.487 * * * \\
{[0.049]}\end{array}$ & $\begin{array}{c}0.286^{* * *} \\
{[0.048]}\end{array}$ & $\begin{array}{c}0.559 * * * \\
{[0.051]}\end{array}$ & $\begin{array}{c}0.509 * * * \\
{[0.047]}\end{array}$ & $\begin{array}{c}0.506 * * * \\
{[0.047]}\end{array}$ & $\begin{array}{c}0.506 * * * \\
{[0.045]}\end{array}$ \\
\hline$\Delta \log$ (private credit / GDP) (t-2) & $\begin{array}{c}-0.226 * * * \\
{[0.050]}\end{array}$ & $\begin{array}{c}-0.329 * * * \\
{[0.055]}\end{array}$ & $\begin{array}{c}-0.235^{* * *} \\
{[0.056]}\end{array}$ & $\begin{array}{c}-0.236^{* * *} \\
{[0.048]}\end{array}$ & $\begin{array}{c}-0.242 * * * \\
{[0.047]}\end{array}$ & $\begin{array}{c}-0.218 * * * \\
{[0.044]}\end{array}$ \\
\hline$\Delta \log$ (private credit / GDP) (t-3) & $\begin{array}{l}0.132 * * \\
{[0.053]}\end{array}$ & $\begin{array}{c}-0.009 \\
{[0.054]}\end{array}$ & $\begin{array}{c}0.113^{* * *} \\
{[0.043]}\end{array}$ & $\begin{array}{c}0.128^{* *} \\
{[0.053]}\end{array}$ & $\begin{array}{c}0.129 * * * \\
{[0.046]}\end{array}$ & $\begin{array}{c}0.139 * * * \\
{[0.046]}\end{array}$ \\
\hline$\Delta \log$ (private credit / GDP) (t-4) & $\begin{array}{c}-0.073^{* *} \\
{[0.032]}\end{array}$ & $\begin{array}{c}-0.220 * * * \\
{[0.047]}\end{array}$ & $\begin{array}{l}-0.063^{*} \\
{[0.034]}\end{array}$ & $\begin{array}{c}-0.085^{* * *} \\
{[0.030]}\end{array}$ & $\begin{array}{c}-0.079 * * * \\
{[0.028]}\end{array}$ & $\begin{array}{l}-0.060^{*} \\
{[0.034]}\end{array}$ \\
\hline Control variable (t-5) & & & $\begin{array}{c}0.001 \\
{[0.001]}\end{array}$ & $\begin{array}{c}0.001 \\
{[0.017]}\end{array}$ & $\begin{array}{c}0.011 \\
{[0.017]}\end{array}$ & $\begin{array}{c}-0.005 \\
{[0.034]}\end{array}$ \\
\hline$\Delta$ Control variable & & & $\begin{array}{c}0.004 \\
{[0.003]}\end{array}$ & $\begin{array}{l}-0.025 \\
{[0.032]}\end{array}$ & $\begin{array}{l}-0.016 \\
{[0.032]}\end{array}$ & $\begin{array}{l}-0.158 * \\
{[0.088]}\end{array}$ \\
\hline$\Delta$ Control variable (t-1) & & & $\begin{array}{c}0.003 \\
{[0.003]}\end{array}$ & $\begin{array}{c}0.031 \\
{[0.026]}\end{array}$ & $\begin{array}{c}0.034 \\
{[0.023]}\end{array}$ & $\begin{array}{c}-0.105 \\
{[0.069]}\end{array}$ \\
\hline$\Delta$ Control variable (t-2) & & & $\begin{array}{c}0.004 \\
{[0.003]}\end{array}$ & $\begin{array}{c}0.021 \\
{[0.032]}\end{array}$ & $\begin{array}{c}0.025 \\
{[0.022]}\end{array}$ & $\begin{array}{c}-0.046 \\
{[0.081]}\end{array}$ \\
\hline$\Delta$ Control variable (t-3) & & & $\begin{array}{c}0.003^{* *} \\
{[0.001]}\end{array}$ & $\begin{array}{c}0.032 \\
{[0.030]}\end{array}$ & $\begin{array}{c}0.011 \\
{[0.018]}\end{array}$ & $\begin{array}{c}-0.11 \\
{[0.112]}\end{array}$ \\
\hline$\Delta$ Control variable $(\mathrm{t}-4)$ & & & $\begin{array}{c}0.002 \\
{[0.001]}\end{array}$ & $\begin{array}{c}0.021 \\
{[0.029]}\end{array}$ & $\begin{array}{c}0.027 \\
{[0.020]}\end{array}$ & $\begin{array}{c}0.016 \\
{[0.102]}\end{array}$ \\
\hline Long-run effect & $\begin{array}{c}1.302 * * * \\
{[0.449]}\end{array}$ & $\begin{array}{l}0.400 * * \\
{[0.198]}\end{array}$ & $\begin{array}{l}0.847^{*} \\
{[0.452]}\end{array}$ & $\begin{array}{l}0.918 * * \\
{[0.455]}\end{array}$ & $\begin{array}{l}1.108 * * \\
{[0.469]}\end{array}$ & $\begin{array}{c}0.655 \\
{[0.449]}\end{array}$ \\
\hline $\begin{array}{l}\text { Observations } \\
\text { ar1 } \\
\text { ar2 } \\
\text { ar3 } \\
\text { ar4 }\end{array}$ & $\begin{array}{c}911 \\
-4.56 \\
-2.35 \\
-0.07 \\
-0.73\end{array}$ & $\begin{array}{c}911 \\
-4.33 \\
-2.17 \\
-0.68 \\
-0.50\end{array}$ & $\begin{array}{c}751 \\
-4.41 \\
-1.91 \\
-0.54 \\
-0.05\end{array}$ & $\begin{array}{c}911 \\
-4.65 \\
-2.33 \\
-0.11 \\
-0.50\end{array}$ & $\begin{array}{c}911 \\
-4.56 \\
-2.36 \\
-0.15 \\
-0.50\end{array}$ & $\begin{array}{c}681 \\
-4.70 \\
-2.26 \\
-0.38 \\
0.00\end{array}$ \\
\hline
\end{tabular}

Robust standard errors in brackets, ${ }^{* * *} \mathrm{p}<0.01,{ }^{* *} \mathrm{p}<0.05,{ }^{*} \mathrm{p}<0.1$. Regressions also include five lags of inflation and GDP per capita, and country and time fixed effects 
Table 8. Regressions with 5 year period panels

\begin{tabular}{|c|c|c|c|c|c|c|c|c|c|c|}
\hline \multirow[b]{2}{*}{ Sample } & \multicolumn{5}{|c|}{ OLS } & \multicolumn{5}{|c|}{ 2SLS } \\
\hline & Full & $\begin{array}{l}\text { Good Property } \\
\text { Rights }\end{array}$ & $\begin{array}{l}\text { Bad Property } \\
\text { Rights }\end{array}$ & Full & $\begin{array}{c}\text { Full } \\
\text { Excl. supervision }\end{array}$ & Full & $\begin{array}{l}\text { Good Property } \\
\text { Rights }\end{array}$ & $\begin{array}{l}\text { Bad Property } \\
\text { Rights }\end{array}$ & Full & $\begin{array}{c}\text { Full } \\
\text { Excl. } \\
\text { supervision }\end{array}$ \\
\hline$\Delta$ Banking reform subindex $(\mathrm{t} / \mathrm{t}-5)$ & $\begin{array}{l}0.402 * * \\
{[0.197]}\end{array}$ & $\begin{array}{l}0.717 * * \\
{[0.337]}\end{array}$ & $\begin{array}{c}0.231 \\
{[0.377]}\end{array}$ & $\begin{array}{l}0.391 \\
{[0.64]}\end{array}$ & $\begin{array}{l}0.137 \\
{[0.19]}\end{array}$ & $\begin{array}{c}-0.36 \\
{[0.642]}\end{array}$ & $\begin{array}{c}0.790^{*} \\
{[0.422]}\end{array}$ & $\begin{array}{l}-0.099 \\
{[0.482]}\end{array}$ & $\begin{array}{l}0.756 \\
{[0.57]}\end{array}$ & $\begin{array}{l}0.321^{*} \\
{[0.18]}\end{array}$ \\
\hline Banking reform subindex (t-5) & $\begin{array}{c}0.548^{*} \\
{[0.290]}\end{array}$ & $\begin{array}{c}1.322 * * * \\
{[0.461]}\end{array}$ & $\begin{array}{l}-0.118 \\
{[0.822]}\end{array}$ & $\begin{array}{l}-0.219 \\
{[0.48]}\end{array}$ & $\begin{array}{l}-0.102 \\
{[0.15]}\end{array}$ & $\begin{array}{c}0.248 \\
{[0.685]}\end{array}$ & $\begin{array}{c}2.028 * * * \\
{[0.581]}\end{array}$ & $\begin{array}{l}-0.732 \\
{[0.684]}\end{array}$ & $\begin{array}{l}-0.041 \\
{[0.49]}\end{array}$ & $\begin{array}{l}-0.113 \\
{[0.17]}\end{array}$ \\
\hline $\begin{array}{l}\Delta \text { Banking reform subindex }(\mathrm{t} / \mathrm{t}-\mathrm{5}) \\
* \text { Constraint on the executive }\end{array}$ & & & & $\begin{array}{l}-0.005 \\
{[0.12]}\end{array}$ & $\begin{array}{l}-0.003 \\
{[0.04]}\end{array}$ & & & & $\begin{array}{l}-0.096 \\
{[0.14]}\end{array}$ & $\begin{array}{l}-0.039 \\
{[0.04]}\end{array}$ \\
\hline $\begin{array}{l}\text { Banking reform subindex (t-5) } \\
\quad{ }^{*} \text { Constraint on the executive }\end{array}$ & & & & $\begin{array}{l}0.158^{*} \\
{[0.08]}\end{array}$ & $\begin{array}{c}0.054^{* *} \\
{[0.03]}\end{array}$ & & & & $\begin{array}{l}0.133 \\
{[0.09]}\end{array}$ & $\begin{array}{l}0.069 * \\
{[0.04]}\end{array}$ \\
\hline Log (Private credit / GDP) (t-5) & $\begin{array}{c}-0.593 * * * \\
{[0.076]}\end{array}$ & $\begin{array}{c}-0.579 * * * \\
{[0.117]}\end{array}$ & $\begin{array}{c}-0.595 * * * \\
{[0.150]}\end{array}$ & $\begin{array}{c}-0.625 * * * \\
{[0.08]}\end{array}$ & $\begin{array}{c}-0.618 * * * \\
{[0.08]}\end{array}$ & $\begin{array}{c}-0.596 * * * \\
{[0.113]}\end{array}$ & $\begin{array}{c}-0.742 * * * \\
{[0.100]}\end{array}$ & $\begin{array}{c}-0.512 * * * \\
{[0.140]}\end{array}$ & $\begin{array}{c}-0.586 * * * \\
{[0.11]}\end{array}$ & $\begin{array}{c}-0.586 * * * \\
{[0.10]}\end{array}$ \\
\hline$\Delta$ Inflation $(\mathrm{t} / \mathrm{t}-5)$ & $\begin{array}{l}-0.095 \\
{[0.089]}\end{array}$ & $\begin{array}{l}-0.107 \\
{[0.112]}\end{array}$ & $\begin{array}{l}-0.235 \\
{[0.259]}\end{array}$ & $\begin{array}{l}-0.074 \\
{[0.08]}\end{array}$ & $\begin{array}{l}-0.065 \\
{[0.09]}\end{array}$ & $\begin{array}{l}-0.205^{*} \\
{[0.109]}\end{array}$ & $\begin{array}{l}-0.100^{*} \\
{[0.058]}\end{array}$ & $\begin{array}{c}-0.37 \\
{[0.372]}\end{array}$ & $\begin{array}{c}-0.185^{*} \\
{[0.09]}\end{array}$ & $\begin{array}{c}-0.210^{* *} \\
{[0.10]}\end{array}$ \\
\hline$\Delta$ Log (GDP per capita) (t/t-5) & $\begin{array}{c}0.948^{* * *} \\
{[0.332]}\end{array}$ & $\begin{array}{c}0.394 \\
{[0.458]}\end{array}$ & $\begin{array}{l}0.969^{*} \\
{[0.575]}\end{array}$ & $\begin{array}{c}0.824 * * * \\
{[0.30]}\end{array}$ & $\begin{array}{c}0.831^{* * *} \\
{[0.30]}\end{array}$ & $\begin{array}{l}0.481^{*} \\
{[0.277]}\end{array}$ & $\begin{array}{c}0.229 \\
{[0.359]}\end{array}$ & $\begin{array}{l}0.942 * * \\
{[0.377]}\end{array}$ & $\begin{array}{l}0.392 \\
{[0.25]}\end{array}$ & $\begin{array}{c}0.468^{*} \\
{[0.27]}\end{array}$ \\
\hline Inflation (t-5) & $\begin{array}{c}-0.092 \\
{[0.088]}\end{array}$ & $\begin{array}{l}-0.108 \\
{[0.112]}\end{array}$ & $\begin{array}{l}-0.237 \\
{[0.256]}\end{array}$ & $\begin{array}{l}-0.074 \\
{[0.08]}\end{array}$ & $\begin{array}{l}-0.068 \\
{[0.09]}\end{array}$ & $\begin{array}{l}-0.205^{*} \\
{[0.109]}\end{array}$ & $\begin{array}{l}-0.103^{*} \\
{[0.059]}\end{array}$ & $\begin{array}{c}-0.373 \\
{[0.371]}\end{array}$ & $\begin{array}{c}-0.185^{*} \\
{[0.09]}\end{array}$ & $\begin{array}{c}-0.210^{* *} \\
{[0.10]}\end{array}$ \\
\hline Log (GDP per capita) (t-5) & $\begin{array}{c}0.747 * * * \\
{[0.171]}\end{array}$ & $\begin{array}{c}0.805^{*} \\
{[0.454]}\end{array}$ & $\begin{array}{l}0.761^{* *} \\
{[0.294]}\end{array}$ & $\begin{array}{c}0.726 * * * \\
{[0.15]}\end{array}$ & $\begin{array}{c}0.740^{* * *} \\
{[0.17]}\end{array}$ & $\begin{array}{l}0.544^{* *} \\
{[0.212]}\end{array}$ & $\begin{array}{c}0.978^{* * *} \\
{[0.334]}\end{array}$ & $\begin{array}{l}0.649 * * \\
{[0.297]}\end{array}$ & $\begin{array}{c}0.634 * * * \\
{[0.16]}\end{array}$ & $\begin{array}{c}0.710^{* * *} \\
{[0.18]}\end{array}$ \\
\hline Observations & 393 & 162 & 149 & 368 & 368 & 235 & 124 & 102 & 215 & 215 \\
\hline R-squared & 0.51 & 0.71 & 0.52 & 0.56 & 0.56 & 0.5 & 0.69 & 0.5 & 0.55 & 0.55 \\
\hline Hansen J stat & & . & . & & & 34.377 & 32.391 & 27.583 & 77.235 & 74.119 \\
\hline $\mathrm{p}$ value & & . & . & & & 0.1258 & 0.18051 & 0.37928 & 0.01 & 0.02 \\
\hline First stage F statistics (excl. IVs) & & & & & & & & & & \\
\hline$\Delta$ Banking reform subindex (t/t-5) & & & & & & 3.64 & 8.68 & 15.76 & 19.53 & 21.69 \\
\hline Banking reform subindex (t-5) & & & & & & 9.23 & 15.05 & 10.51 & 35.01 & 30.55 \\
\hline$\Delta$ Banking reform subindex $(t / t-5)$ & KCONST & & & & & & & & 22.26 & 25.82 \\
\hline Banking reform subindex $(\mathrm{t}-5) * X$ & DNST & & & & & & & & 44.86 & 35.1 \\
\hline
\end{tabular}

Robust standard errors in brackets, ${ }^{* * *} \mathrm{p}<0.01,{ }^{* *} \mathrm{p}<0.05,{ }^{*} \mathrm{p}<0.1$. Regressions include country and year fixed effects.

Instrumented variables are $\Delta$ Banking reform subindex $(\mathrm{t} / \mathrm{t}-5)$ and Banking reform subindex $(\mathrm{t}-5)$, and interactions with constraint on the executive

Instruments include five year change, five year lags, and averages of the changes between $t-5$ and $t-10$, of political allies for each of the subcomponents of the financial reform index 
Table 9. Impact of specific banking sector reforms on financial depth

Good property right sub-sample

$\begin{array}{lcccccccc}(1) & (2) & (3) & (4) & (5) & (6) & (7) & (8) & (9)\end{array}$

\begin{tabular}{|c|c|c|c|c|c|c|c|c|c|c|}
\hline \multirow{2}{*}{$\begin{array}{l}\text { Subindex } \\
\text { Sample: }\end{array}$} & \multicolumn{2}{|c|}{ Directed credit } & \multicolumn{2}{|c|}{$\begin{array}{l}\text { (3) } \\
\text { Interest rate controls }\end{array}$} & \multicolumn{2}{|c|}{ Competition policy } & \multicolumn{2}{|c|}{ Banking supervision } & \multicolumn{2}{|c|}{ Privatization } \\
\hline & Full & Developing & Full & Developing & Full & Developing & Full & Developing & Full & Developing \\
\hline Log (private credit / GDP) (t-5) & $\begin{array}{c}-0.097 * * * \\
{[0.027]}\end{array}$ & $\begin{array}{c}-0.188 * * * \\
{[0.025]}\end{array}$ & $\begin{array}{c}0.095^{* * *} \\
{[0.027]}\end{array}$ & $\begin{array}{c}-0.185^{* * *} \\
{[0.028]}\end{array}$ & $\begin{array}{c}0.100^{* * *} \\
{[0.026]}\end{array}$ & $\begin{array}{c}-0.210^{* * *} \\
{[0.030]}\end{array}$ & $\begin{array}{c}-0.099 * * * \\
{[0.027]}\end{array}$ & $\begin{array}{c}-0.196 * * * \\
{[0.026]}\end{array}$ & $\begin{array}{c}0.108^{* * *} \\
{[0.024]}\end{array}$ & $\begin{array}{c}-0.192^{* * *} \\
{[0.024]}\end{array}$ \\
\hline$\Delta \log$ (private credit / GDP) (t-1) & $\begin{array}{c}0.443 * * * \\
{[0.053]}\end{array}$ & $\begin{array}{c}0.258 * * * \\
{[0.067]}\end{array}$ & $\begin{array}{c}0.454 * * * \\
{[0.052]} \\
-\end{array}$ & $\begin{array}{c}0.290 * * * \\
{[0.060]}\end{array}$ & $\begin{array}{c}0.447 * * * \\
{[0.053]} \\
-\end{array}$ & $\begin{array}{c}0.255^{* * * *} \\
{[0.065]}\end{array}$ & $\begin{array}{c}0.460^{* * *} \\
{[0.053]}\end{array}$ & $\begin{array}{c}0.281^{* * * *} \\
{[0.059]}\end{array}$ & $\begin{array}{c}0.446 * * * \\
{[0.051]} \\
-\end{array}$ & $\begin{array}{c}0.285 * * * \\
{[0.066]}\end{array}$ \\
\hline$\Delta \log$ (private credit / GDP) (t-2) & $\begin{array}{c}-0.284 * * * \\
{[0.056]}\end{array}$ & $\begin{array}{c}-0.318 * * * \\
{[0.069]}\end{array}$ & $\begin{array}{c}0.271^{* * *} \\
{[0.056]}\end{array}$ & $\begin{array}{c}-0.288^{* * *} \\
{[0.073]}\end{array}$ & $\begin{array}{c}0.288^{* * *} \\
{[0.054]}\end{array}$ & $\begin{array}{c}-0.327 * * * \\
{[0.061]}\end{array}$ & $\begin{array}{c}-0.280 * * * \\
{[0.055]}\end{array}$ & $\begin{array}{c}-0.320 * * * \\
{[0.066]}\end{array}$ & $\begin{array}{c}0.278 * * * \\
{[0.053]}\end{array}$ & $\begin{array}{c}-0.300 * * * \\
{[0.064]}\end{array}$ \\
\hline$\Delta \log$ (private credit / GDP) (t-3) & $\begin{array}{c}0.05 \\
{[0.051]}\end{array}$ & $\begin{array}{c}-0.037 \\
{[0.056]}\end{array}$ & $\begin{array}{c}0.057 \\
{[0.051]} \\
-\end{array}$ & $\begin{array}{c}-0.034 \\
{[0.055]}\end{array}$ & $\begin{array}{c}0.05 \\
{[0.054]} \\
-\end{array}$ & $\begin{array}{c}-0.056 \\
{[0.056]}\end{array}$ & $\begin{array}{c}0.062 \\
{[0.048]}\end{array}$ & $\begin{array}{l}-0.017 \\
{[0.044]}\end{array}$ & $\begin{array}{c}0.056 \\
{[0.046]} \\
-\end{array}$ & $\begin{array}{c}-0.029 \\
{[0.046]}\end{array}$ \\
\hline$\Delta \log$ (private credit / GDP) (t-4) & $\begin{array}{c}-0.133^{* * *} \\
{[0.034]}\end{array}$ & $\begin{array}{c}-0.200 * * * \\
{[0.054]}\end{array}$ & $\begin{array}{c}0.126 * * * \\
{[0.032]}\end{array}$ & $\begin{array}{c}-0.190 * * * \\
{[0.045]}\end{array}$ & $\begin{array}{c}0.134^{* * *} \\
{[0.033]}\end{array}$ & $\begin{array}{c}-0.204^{* * *} \\
{[0.051]}\end{array}$ & $\begin{array}{c}-0.126 * * * \\
{[0.032]}\end{array}$ & $\begin{array}{c}-0.200 * * * \\
{[0.049]}\end{array}$ & $\begin{array}{c}0.135^{* * *} \\
{[0.034]}\end{array}$ & $\begin{array}{c}-0.188 * * * \\
{[0.053]}\end{array}$ \\
\hline Banking reform subindex (t-5) & $\begin{array}{l}0.060 * * \\
{[0.024]}\end{array}$ & $\begin{array}{l}0.090^{*} \\
{[0.048]}\end{array}$ & $\begin{array}{c}0.026 \\
{[0.019]}\end{array}$ & $\begin{array}{c}0.013 \\
{[0.045]}\end{array}$ & $\begin{array}{l}0.050^{*} \\
{[0.030]}\end{array}$ & $\begin{array}{l}0.103^{* *} \\
{[0.050]}\end{array}$ & $\begin{array}{c}0.001 \\
{[0.021]}\end{array}$ & $\begin{array}{c}-0.065 \\
{[0.064]}\end{array}$ & $\begin{array}{c}0.068 * * * \\
{[0.022]}\end{array}$ & $\begin{array}{c}0.006 \\
{[0.035]}\end{array}$ \\
\hline$\Delta$ Banking reform subindex & $\begin{array}{c}-0.015 \\
{[0.027]}\end{array}$ & $\begin{array}{c}-0.027 \\
{[0.043]}\end{array}$ & $\begin{array}{c}0.02 \\
{[0.021]}\end{array}$ & $\begin{array}{c}0.018 \\
{[0.037]}\end{array}$ & $\begin{array}{c}0.066^{*} \\
{[0.035]}\end{array}$ & $\begin{array}{c}0.125 \\
{[0.076]}\end{array}$ & $\begin{array}{c}-0.031 \\
{[0.024]}\end{array}$ & $\begin{array}{l}-0.109 * \\
{[0.058]}\end{array}$ & $\begin{array}{c}0.033 \\
{[0.041]}\end{array}$ & $\begin{array}{l}-0.037 \\
{[0.060]}\end{array}$ \\
\hline$\Delta$ Banking reform subindex (t-1) & $\begin{array}{c}0.051 \\
{[0.031]}\end{array}$ & $\begin{array}{c}0.059 \\
{[0.054]}\end{array}$ & $\begin{array}{c}0.05 \\
{[0.030]}\end{array}$ & $\begin{array}{c}0.069 \\
{[0.068]}\end{array}$ & $\begin{array}{c}0.044 \\
{[0.029]}\end{array}$ & $\begin{array}{c}0.093 \\
{[0.073]}\end{array}$ & $\begin{array}{c}-0.008 \\
{[0.024]}\end{array}$ & $\begin{array}{c}-0.054 \\
{[0.069]}\end{array}$ & $\begin{array}{l}0.058^{*} \\
{[0.031]}\end{array}$ & $\begin{array}{c}0.023 \\
{[0.045]}\end{array}$ \\
\hline$\Delta$ Banking reform subindex (t-2) & $\begin{array}{l}0.055^{* *} \\
{[0.026]}\end{array}$ & $\begin{array}{c}0.085 \\
{[0.056]}\end{array}$ & $\begin{array}{c}0.031 \\
{[0.022]}\end{array}$ & $\begin{array}{c}0.022 \\
{[0.053]}\end{array}$ & $\begin{array}{c}0.045 \\
{[0.029]}\end{array}$ & $\begin{array}{c}0.07 \\
{[0.073]}\end{array}$ & $\begin{array}{c}-0.001 \\
{[0.034]}\end{array}$ & $\begin{array}{c}-0.094 \\
{[0.076]}\end{array}$ & $\begin{array}{c}0.024 \\
{[0.022]}\end{array}$ & $\begin{array}{l}-0.007 \\
{[0.034]}\end{array}$ \\
\hline$\Delta$ Banking reform subindex (t-3) & $\begin{array}{l}0.071^{* *} \\
{[0.032]}\end{array}$ & $\begin{array}{l}0.118^{*} \\
{[0.063]}\end{array}$ & $\begin{array}{c}0.008 \\
{[0.022]}\end{array}$ & $\begin{array}{l}-0.052 \\
{[0.042]}\end{array}$ & $\begin{array}{c}0.064 \\
{[0.044]}\end{array}$ & $\begin{array}{c}0.166 * * * \\
{[0.060]}\end{array}$ & $\begin{array}{l}-0.005 \\
{[0.030]}\end{array}$ & $\begin{array}{c}-0.057 \\
{[0.075]}\end{array}$ & $\begin{array}{c}0.025 \\
{[0.040]}\end{array}$ & $\begin{array}{c}-0.028 \\
{[0.052]}\end{array}$ \\
\hline$\Delta$ Banking reform subindex (t-4) & $\begin{array}{c}0.057 \\
{[0.040]}\end{array}$ & $\begin{array}{c}0.101 \\
{[0.074]}\end{array}$ & $\begin{array}{l}0.039^{* *} \\
{[0.018]}\end{array}$ & $\begin{array}{c}0.028 \\
{[0.051]}\end{array}$ & $\begin{array}{l}0.071^{* *} \\
{[0.034]}\end{array}$ & $\begin{array}{c}0.154^{* * *} \\
{[0.055]}\end{array}$ & $\begin{array}{c}0.017 \\
{[0.033]}\end{array}$ & $\begin{array}{c}-0.005 \\
{[0.064]}\end{array}$ & $\begin{array}{c}0.024 \\
{[0.020]}\end{array}$ & $\begin{array}{c}-0.027 \\
{[0.033]}\end{array}$ \\
\hline Observations & 911 & 428 & 911 & 428 & 911 & 428 & 911 & 428 & 911 & 428 \\
\hline R-squared & 0.6 & 0.68 & 0.59 & 0.67 & 0.6 & 0.68 & 0.59 & 0.67 & 0.6 & 0.67 \\
\hline
\end{tabular}

$* * * \mathrm{p}<0.01, * * \mathrm{p}<0.05, * \mathrm{p}<0.1$. Robust standard errors in brackets. Regressions also include five lags of inflation and GDP per capita, and country and time fixed effects. Robust standard errors in brackets 
Figure 1: Financial Reforms by regions

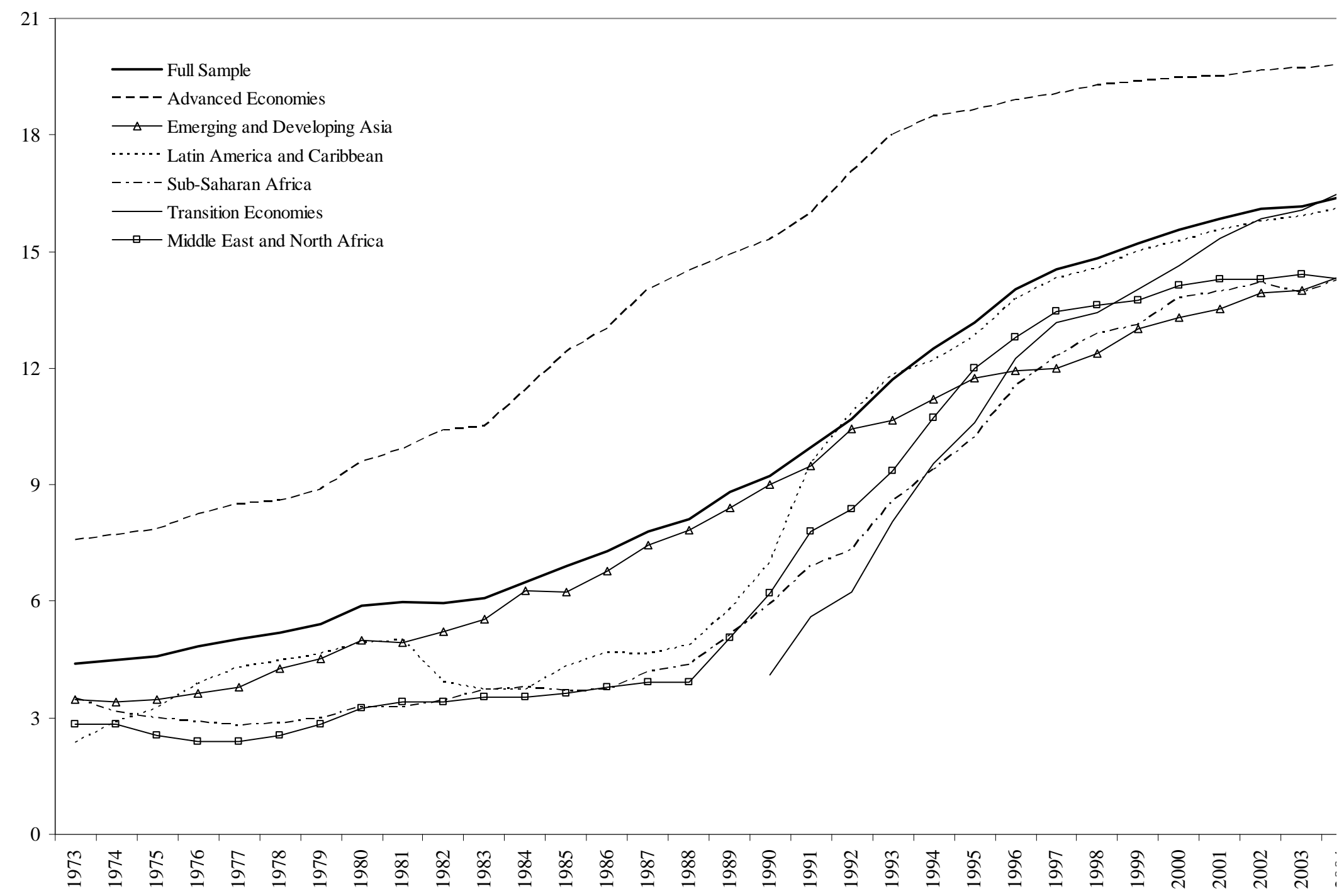


Figure 2: Private credit to GDP around episodes of banking reforms

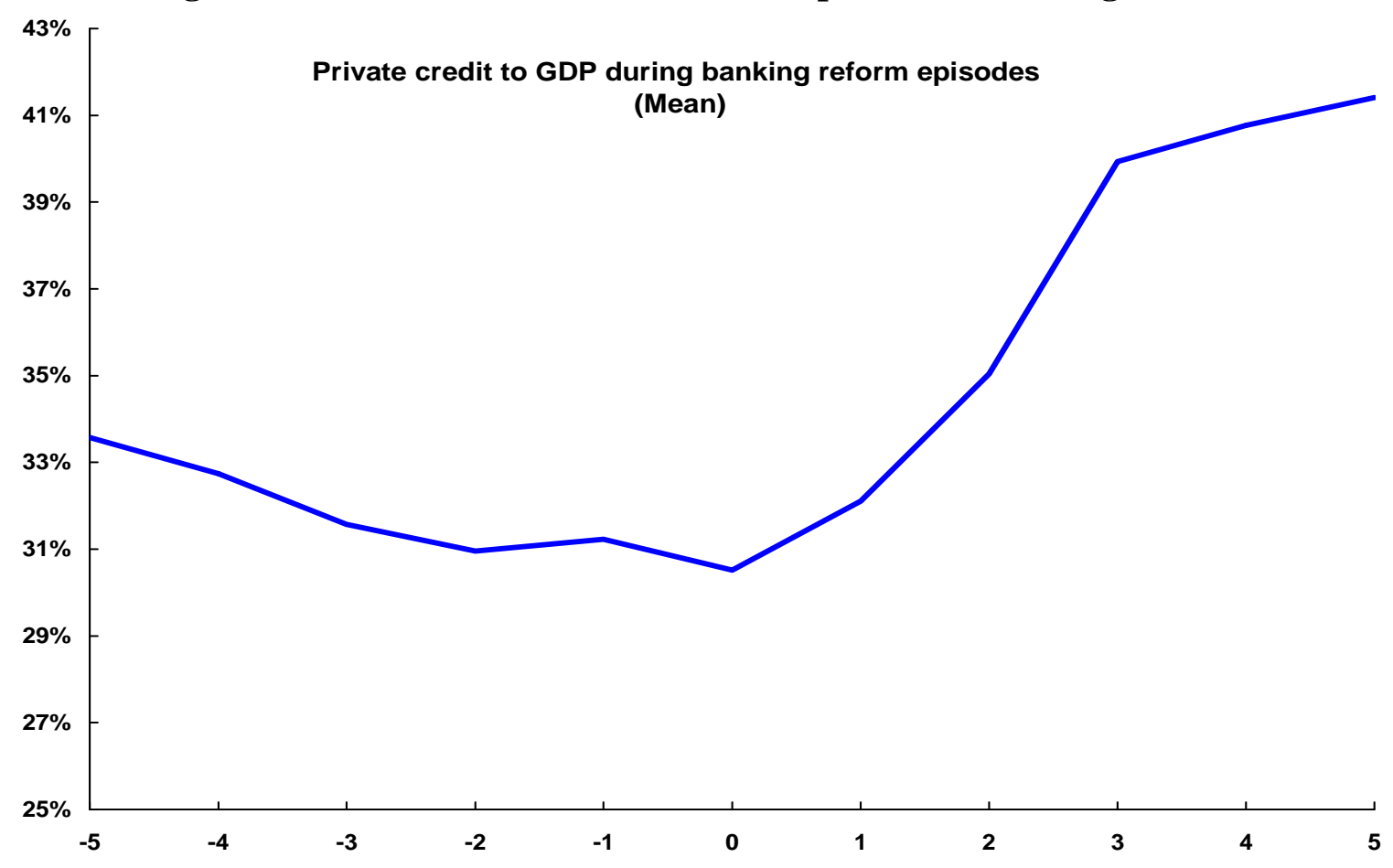

Figure 3: Financial depth and banking reform index - evolution of cross-sectional dispersion

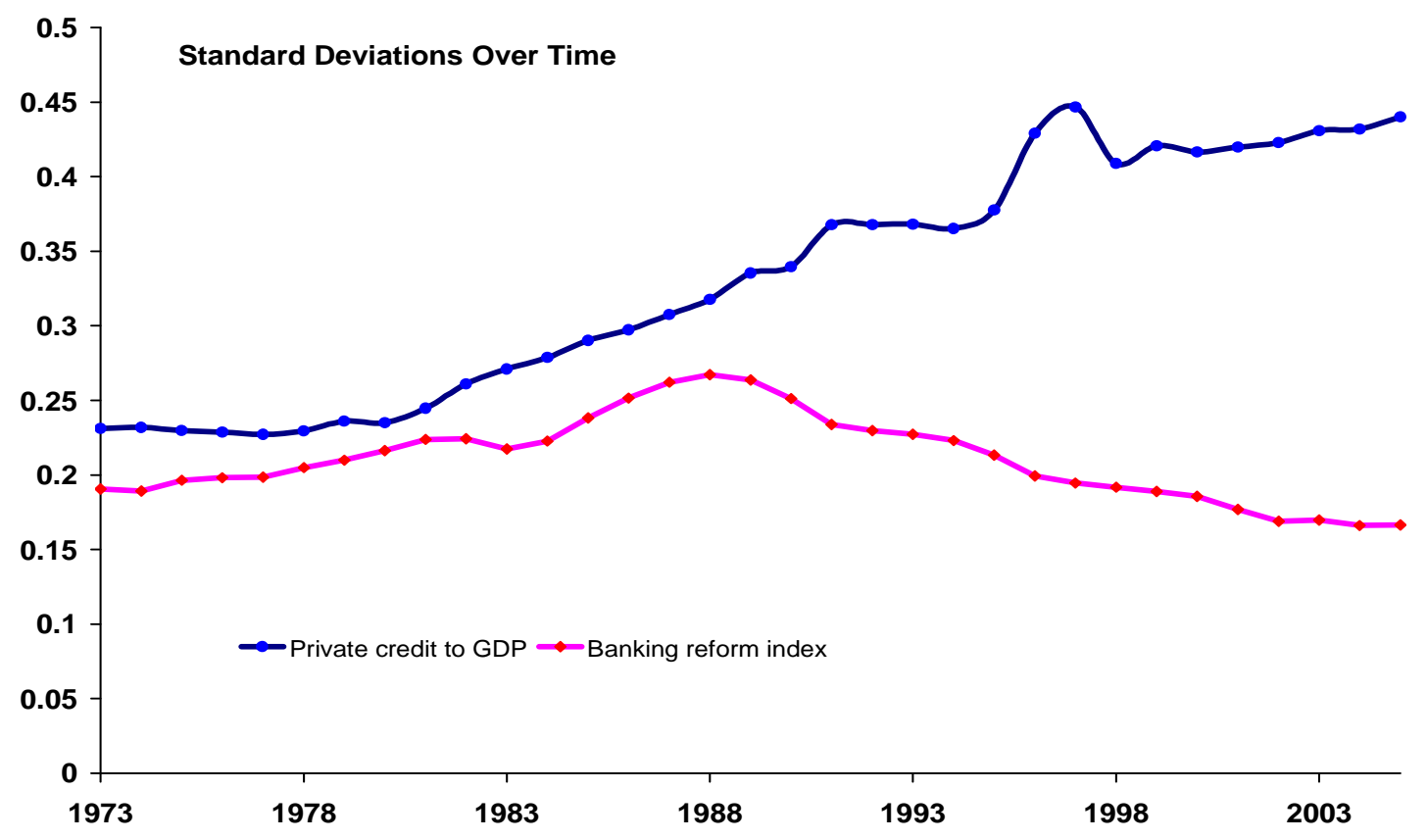


Figure 4: Financial depth and banking reform index - correlation over time

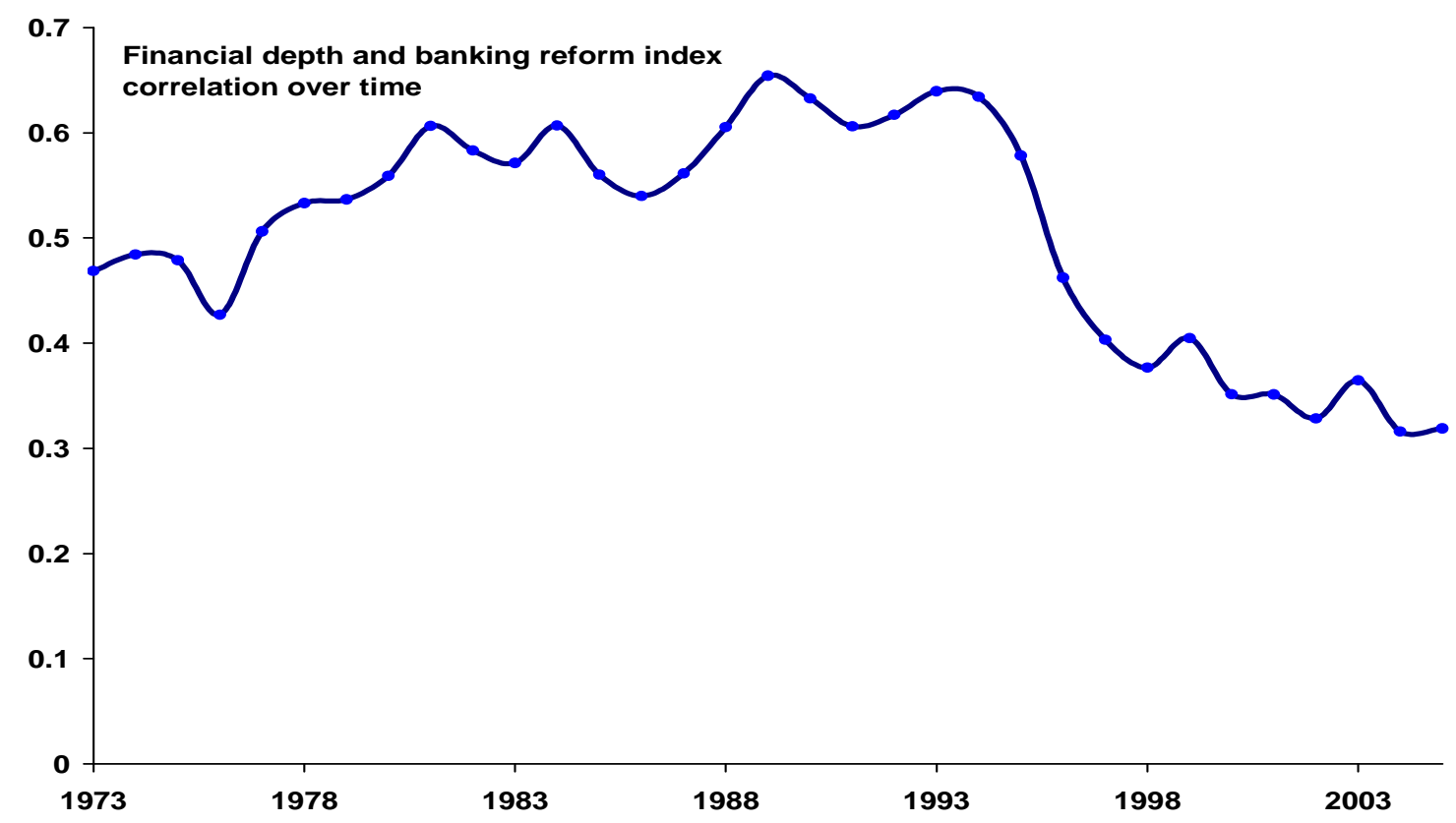


Figure 5. Estimated effect of banking reforms on the private credit to GDP ratio
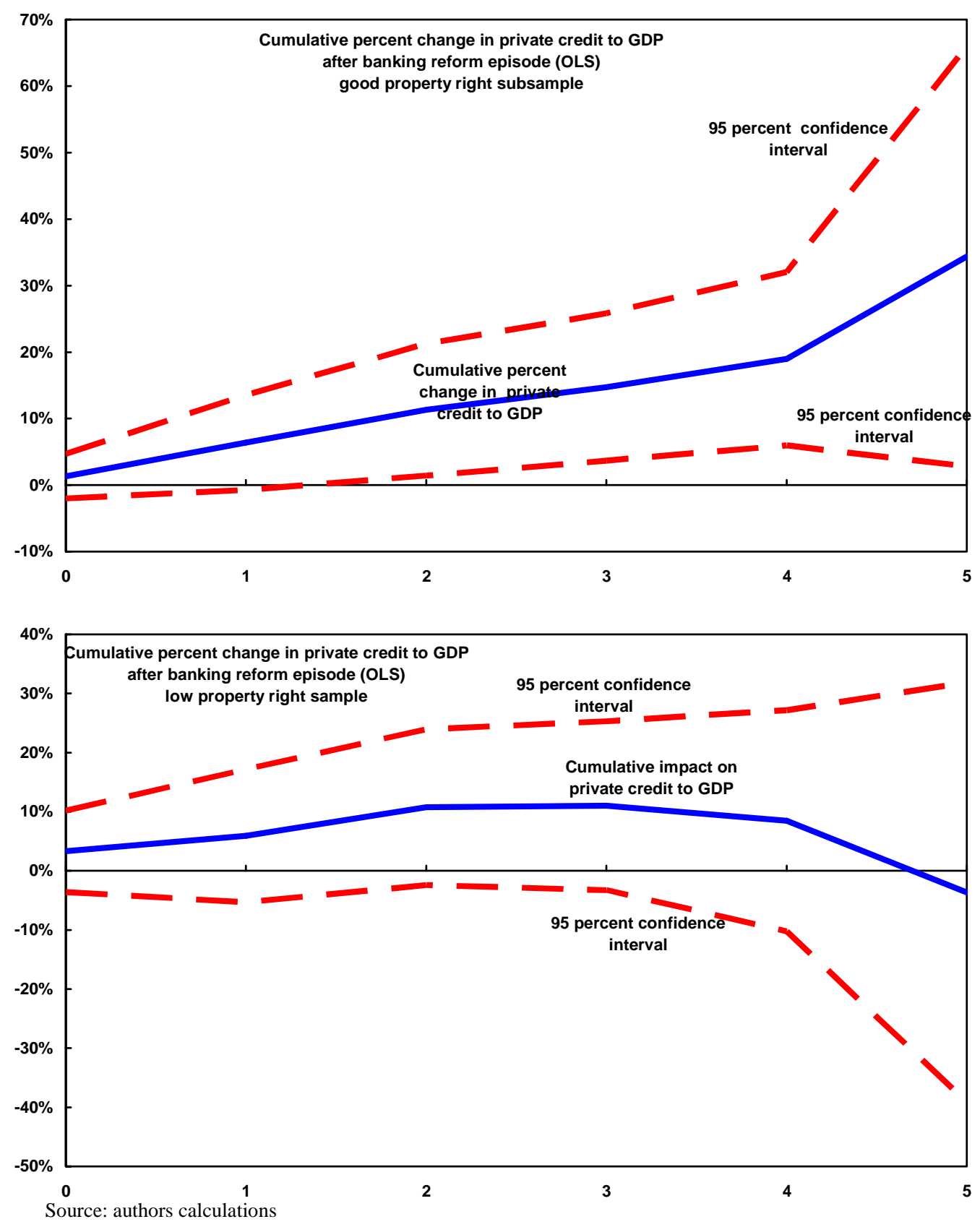


\section{Data Appendix}

\begin{tabular}{|c|c|c|}
\hline Variable & Definition & Source \\
\hline Private credit to GDP & Deposit Money Bank Claims on the Private Sector & IMF, International Financial Statistics \\
\hline GDP & GDP at current prices in local currrency & IMF, International Financial Statistics \\
\hline Index of banking reform & Simple average of 5 banking reform indices & Abiad, Detragiache, Tressel (2008) \\
\hline Inflation & Rate of change in consumer price index & IMF, International Financial Statistics \\
\hline GDP per capita & Log of GDP divided by population & World Bank \\
\hline Property rights protection & Constraints on the Executive & Polity IV Project--www.systemicpeace.org/polity \\
\hline Common Law and civil law dummies & 0-1 dummies of legal origin (English or French) & La Porta et al. (1998) \\
\hline Index of creditor rights & Protection of creditor rights in bankruptcy & Djiankov, McLiesh, and Shleifer (2007) \\
\hline Enforcement & Number of days to enforce a contract & World Bank, Doing business database, 2004 \\
\hline Banking crisis dummy & Dummy for start date of a banking crisis & Demirguc-Kunt and Detragiache (2005) \\
\hline General Government Balance to GDP & Ratio of fiscal balance to GDP & IMF, International Financial Statistics \\
\hline Securities market subindex & Index of policies to develop stock and bond markets & Abiad, Detragiache, Tressel (2008) \\
\hline International capital flows subindex & Index of lack of restrictions on international financial credits & Abiad, Detragiache, Tressel (2008) \\
\hline Average tariff index & Normalized index of average import tariffs & IMF (2008) \\
\hline \multicolumn{3}{|l|}{ Banking reform subindices } \\
\hline Directed credit subindex & Index of lack of restrictions on allocation of credit & Abiad, Detragiache, Tressel (2008) \\
\hline Interest rate subindex & Index of deposit and lending interest rate liberalization & Abiad, Detragiache, Tressel (2008) \\
\hline Competition subindex & Index of lack of entry barriers & Abiad, Detragiache, Tressel (2008) \\
\hline Supervision subindex & Index of quality of banking supervision & Abiad, Detragiache, Tressel (2008) \\
\hline Privatisation subindex & Index of degree of privatization & Abiad, Detragiache, Tressel (2008) \\
\hline
\end{tabular}




\section{APPENDIX: EMPIRICAL SPECIFICATION}

We consider the following dynamic panel specification:

$y_{i, t}=\alpha_{0}+\sum_{j=1}^{N} \beta_{j} \cdot y_{i, t-j}+\sum_{j=0}^{N} \gamma_{j} \cdot I_{i, t-j}+\sum_{j=0}^{N} \varphi_{j} \cdot X_{i, t-j}+\varepsilon_{i t}$

Subtracting $y_{i, t-1}$ from both sides of the equations yields:

$y_{i, t}-y_{i, t-1}=\Delta y_{i, t}=\alpha_{0}+\left(\beta_{1}-1\right) \cdot y_{i, t-1}+\sum_{j=2}^{N} \beta_{j} \cdot y_{i, t-j}+\sum_{j=0}^{N} \gamma_{j} \cdot I_{i, t-j}+\sum \varphi_{j} \cdot X_{i, t-j}+\varepsilon_{i t}$

Next, subtracting $\left(\beta_{1}-1\right) \cdot y_{i, t-2}$ from the second term and adding it back in the third term gives:

$\Delta y_{i, t}=\alpha_{0}+\left(\beta_{1}-1\right) \cdot \Delta y_{i, t-1}+\left(\beta_{1}+\beta_{2}-1\right) \cdot y_{i, t-2}+\sum_{j=3}^{N} \beta_{j} \cdot y_{i, t-j}+\sum_{j=0}^{N} \gamma_{j} \cdot I_{i, t-j}+\sum \varphi_{j} \cdot X_{i, t-j}+\varepsilon_{i t}$

Repeating the same step consecutively with $y_{i, t-3}, \ldots, y_{i, t-N}$, we finally obtain:

$\Delta y_{i, t}=\alpha_{0}+\sum_{j=1}^{N-1}\left(\sum_{u=1}^{j} \beta_{u}-1\right) \cdot \Delta y_{i, t-j}+\left(\sum_{u=1}^{N} \beta_{u}-1\right) \cdot y_{i, t-N}+\sum_{j=1}^{N} \gamma_{j} \cdot I_{i, t-j}+\sum_{j=0}^{N} \varphi_{j} \cdot X_{i, t-j}+\varepsilon_{i t}$

The same procedure applied to $I_{i, t-2}, \ldots, I_{i, t-N}$ on the one hand, and to $X_{i, t-2}, \ldots, X_{i, t-N}$ on the other hand gives the error correction model of equation (2):

$$
\begin{aligned}
& \Delta y_{i t}=\sum_{j=1}^{N-1}\left(\sum_{u=1}^{j} \beta_{u}-1\right) \cdot \Delta y_{i, t-j}+\left(\sum_{u=1}^{N} \beta_{u}-1\right) \cdot y_{i, t-N}+\sum_{j=0}^{N-1}\left(\sum_{u=0}^{j} \gamma_{u}\right) \cdot \Delta I_{i, t-j}+\sum_{j=0}^{N-1}\left(\sum_{u=0}^{j} \varphi_{u}\right) \cdot \Delta X_{i, i t-j} \\
& +\left(\sum_{u=0}^{N} \gamma_{u}\right) \cdot I_{i, t=N}+\left(\sum_{u=0}^{N} \varphi_{u}\right) \cdot X_{i, t-N}+\varepsilon_{i t}
\end{aligned}
$$

